
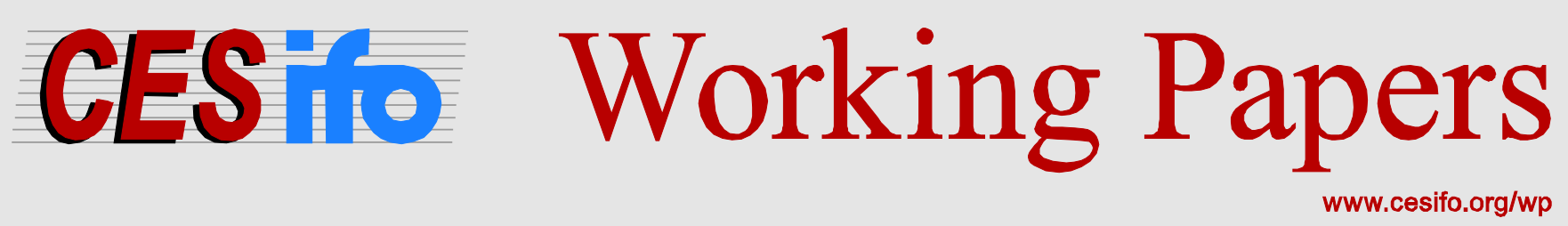

\title{
Investor Taxation, Firm Heterogeneity and Capital Structure Choice
}

\author{
Magdalena Haring \\ Rainer Niemann \\ Silke Rünger
}

\section{CESIFO WORKING PAPER No. 6098 \\ CATEgORY 1: PUBlic FinANCE \\ SEPTEMBER 2016}
An electronic version of the paper may be downloaded
- from the SSRN website:
- from the RePEc website:
- from the CESifo website: WwW.SSRN.com
www.RePEc.org
www.CESifo-group.org/wp




\title{
Investor Taxation, Firm Heterogeneity and Capital Structure Choice
}

\begin{abstract}
We analyze the effect of investor level taxes, firm-specific ownership structure and firm-specific payout policy on firms' capital structure choice. Our analysis is based on data for 10,983 firms from 13 Central and Eastern European (CEE) countries over the time period 2002-2012. Our results show a significant impact of the net tax benefit of debt on the debt ratio of firms. Ignoring firm heterogeneity, an increase in the net tax benefit of debt by 10 percentage points leads to an increase in the debt ratio of 2.49 percentage points. Taking into account investorlevel taxation and firm heterogeneity, an increase in the net tax benefit of debt of 10 percentage points leads to an increase in the debt ratio of only 1.27 percentage points, if the firm's largest individual domestic owner has more than $50 \%$ of the shares. If all individual domestic owners together have more than $50 \%$ of the shares, an increase in the net tax benefit of debt of 10 percentage points leads to a negligible increase in the debt ratio of 0.05 percentage points.
\end{abstract}

JEL-Codes: G320, H240, H250, H320.

Keywords: financing policy, debt ratio, tax benefit, firm ownership, firm heterogeneity.

Magdalena Haring
University of Graz
Institute of Accounting and Taxation
Universitaetsstr. 15/G2
Austria - 8010 Graz
magdalena.haring@gmail.com

Magdalena Haring

Universitaetsstr. 15/G2

magdalena.haring@gmail.com

\author{
Rainer Niemann \\ University of Graz \\ Institute of Accounting and Taxation \\ Universitaetsstr. 15/G2 \\ Austria-8010 Graz \\ niemann@uni-graz.at
}

\author{
Silke Rünger \\ University of Graz \\ Institute of Accounting and Taxation \\ Universitaetsstr. 15/G2 \\ Austria - $8010 \mathrm{Graz}$ \\ silke.ruenger@uni-graz.at
}

The authors thank Kay Blaufus, Michael Overesch and participants at the 2012 annual meeting of the German Academic Association for Business Research (VHB) in Bozen, the 2012 Workshop on Empirical Research in Taxation in Mannheim and the 2014 EAA Annual Congress in Tallinn for helpful comments and suggestions on earlier versions of this paper. Financial support by the Austrian Science Fund (FWF) [P 22324-G1] is gratefully acknowledged. 


\section{Introduction}

Starting with the seminal work of Modigliani / Miller (1958), the effects of taxes on the capital structure of a firm have been under ongoing investigation within research. From a theoretical point of view, Miller (1977) showed that both corporate and investor level taxes must be considered in capital structure choices and that the benefit arising from interest deductibility at the corporate level has to be weighed against the so-called personal tax penalty. A personal tax penalty occurs at the investor level as personal income tax on interest income from debt is often higher than the personal income tax on equity income (dividends and capital gains). Including investor level taxes requires a precise measurement of the investor level tax rates on interest, dividends and capital gains. In addition, investor level tax rates are driven by two aspects of firm heterogenity: firm-specific ownership structure and firm-specific payout policy. Several studies have highlighted the costs and benefits that arise from conflict between minority and majority owners (see Shleifer/Vishny (1986)) and also between owners and management (see Jensen/Meckling (1976)). Following their argumentation, conflicts between majority and minority owners, or owners and management might prevent a tax-efficient capital structure of the firm. In addition, investor level taxes might differ among owner types such as domestic and foreign owners or individual and corporate owners, which is why investor level tax rates depend on the firm-specific owner types and ownership structure. Another source of firm heterogeneity that influences investor level taxes is payout policy. Payments made to equity holders can take the form of dividends or share repurchases, leading to either taxation of dividend income or capital gains. Dividends are taxed at distribution, whereas taxation of capital gains can be deferred until the realization of the gain. In this paper, we integrate both firm-specific payout policy and firm-specific ownership structure and their interplay with investor level taxes into the analysis of capital structure choice.

So far, little attention has been given to the interplay of investor level taxes and firm heterogeneity (ownership structure and payout policy) in capital structure literature. Three papers have recently addressed the influence of ownership structures on capital structure choice. Pindado / de la Torre (2011) analyze the effect of managerial ownership and ownership concentration on a firm's capital structure, but do not include taxes into their analysis. They show that ownership concentration encourages debt financing. Krämer (2015) analyzes how ownership affects the relationship between taxes and capital structure using a sample of 40 European countries. His results show that the effect of taxes on corporate capital structure is stronger for firms with concentrated ownership. Additionally, he finds that the conflict of interest between majority and minority shareholders 
drives down the tax effect. His analysis controls for corporate taxes and taxes on interest, but does not include investor level taxes. Babbel et al. (2015) analyze the influence of different investor tax preferences on the capital structure choice, using the Miller (1977) tax incentive index calculated for the largest owner. Although the Miller (1977) tax incentive index includes investor level taxes, it is calculated based on the assumption that all payments to equity holders are in the form of dividends and therefore neglects capital gains taxation. Gordon / MacKie-Mason (1990) are the first to include investor level taxes and payout policy of the firm into the calculation of the net tax benefit of debt. Investigating the influence of the US tax reform act of 1986, their results show an increase in the net tax benefit of debt after the tax reform. Graham (1999) also tests whether investor taxes have a significant impact on the corporate capital structure using firm-level payout data. He finds a significant positive relationship between the net tax benefit of debt and the corporate debt level. Whereas Gordon / MacKie-Mason (1990) do not address the problem of whether firm-specific ownership structure has an influence on the calculated net tax benefit of debt, results in Graham (1999) imply that it is important to use firm-specific information when adjusting for personal taxes and that the owners of the firm sort into specific tax clienteles when it comes to capital structure choice. Further, Graham (1999) does not control for firm-specific ownership structures in his analysis.

We use the Gordon / MacKie-Mason (1990) and Graham (1999) definition of the net tax benefit of debt to test the effect of taxes on capital structure choice. Our analysis focuses upon the effect of investor taxes on capital structure choices and adds to prior research by explicitly controlling for firm heterogeneity caused by ownership structure and payout policy. We are able to observe the shares held by all owners of the sample firms year by year. This allows us to use a more precise measure of ownership than previous research as we control for changes in ownership over time. We combine firm heterogeneity caused by different ownership structures with the firm-specific net tax benefit of debt, including firm-specific payout data. This way we estimate a model of the capital structure choice that considers investor level taxes and the observed payout policy of the firm, as well as the observed ownership structure of the firm. Controlling for firm heterogeneity, our results provide a more precise estimation of the effect of taxes on capital structure choice.

Our work is based on well-established theories with respect to capital structure choice. Corporate taxes were found to influence the capital structure choice starting with Modgliani / Miller (1963), who showed that the best financing strategy would be to maximize debt financing as this adds value to the levered firm due to the tax shield generated by deductible interest payments. Based on their work, several theories of how to determine the optimal level of debt were developed in the subsequent years. According to the trade-off 
theory (Baxter (1967) and Kraus / Litzenberger (1973)) firms balance the tax advantage of debt against the disadvantage of financial distress. Among the studies empirically testing the trade-off theory that included corporate taxation, MacKie-Mason (1990), Dhaliwal et al. (1992), Trezevant (1992) and Cloyd (1997) all find a significant positive influence of corporate taxes on debt financing. Other theories such as the free cash flow theory (Jensen (1986) and Zwiebel (1996)) or the pecking order theory (Myers / Majluf (1984)) all focus on the impact of agency aspects on capital structure choices. Beside Gordon / MacKie-Mason (1990) and Graham (1999), only a few studies have considered investor level taxes (see Givoly et al. (1992), Rajan / Zingales (1995), Overesch / Voeller (2010) and recently, Faccio / Xu (2015)). Overesch / Voeller (2010) study the effect of investor taxes on capital structure choices in a European setting using data on 814,112 European firms. The authors find that higher tax benefits of debt have the expected significant positive effect on a firms's debt level. Although investor level dividend and capital gains taxes are considered in the model, the authors do not calculate combined tax rates on equity based on the firm-specific payout structure. In addition, firm heterogeneity with respect to ownership is not considered in the analysis. Faccio / Xu (2015) analyze 29 OECD countries over the years 1992-2009 and find taxes to be as important as other traditional variables in explaining capital structure choices. Results are stronger among dividend payers and firms that are more likely to have an individual marginal investor. Contrary to our analysis, investor level taxes on capital gains are not considered in their analysis.

Our analysis is based on data for 10,983 firms from 13 Central and Eastern European (CEE) countries. We have chosen this set of countries for several reasons: From an institutional point of view, most firms in CEE countries are organized (and taxed) as corporations rather than partnerships, which makes it especially important to consider taxes at both corporate and investor level. Additionally, individual ownership is very high in CEE firms and individual domestic owners are typically the largest owner group. Again, this requires considering investor level taxes as well as firm-specific payout policy when calculating the net tax benefit of debt. From a tax standpoint, tax competition in these countries leads to several substantial changes in tax systems over our sample period 2002-2012. These changes lead to a high variation in observed tax rates over time. Furthermore, CEE countries apply constant marginal tax rates on all sources of income relevant to our analysis (that is, corporate, interest, dividend, and capital gains income). Contrary to using other (European) countries applying progressive tax rates, our setting allows us to calculate the exact investor level tax burden without need for investor specific information such as the level of other income or holding periods. 
The countries in our sample are former transition economies. As Klapper et al. (2002) point out, these economies differ from market economies, i.e., the US or Western Europe in economic aspects such as a concentration of firms in the industrial and manufacturing sector, the underdevelopment of financial systems (inability to borrow long-term caused by inflation and weak legal protection) and low legal and governance standards. Therefore, special attention has to be given to the question whether traditional capital structure theories, as assumed by the model of Gordon / MacKie-Mason (1990), can be applied to CEE firms. Results from Klapper et al. (2002), Berk (2006) and Delcoure (2007) show that both the trade-off theory and the pecking order theory can explain capital structure choices in the CEE countries included in our analysis.

Our results show a significant impact of the net tax benefit of debt on the debt ratio of firms. Ignoring firm heterogeneity, an increase in the net tax benefit of debt by 10 percentage points leads to an increase in debt ratios by 2.49 percentage points. Considering firm-specific payout policy, we show that the effect of the net tax benefit of debt on debt ratios is significantly reduced and that an increase in the net tax benefit of debt by 10 percentage points leads to an increase in debt ratios by only 0.94 percentage points. The reduction is driven by the discounting effect of deferred realization of capital gains in conjunction with different statutory tax rates on dividends and capital gains. Adding firm-specific ownership information to our regression shows that as the number of individual domestic owners increases, the effect of the net tax benefit of debt on debt ratios decreases. The effect of the net tax benefit of debt on debt ratios is higher for a lower ownership concentration of the firm. Taking into account investor-level taxation and both sources of firm heterogenity (ownership and payout ratio), an increase in the net tax benefit of debt by 10 percentage points leads to an increase in debt ratios by 1.27 percentage points, if the firm's largest individual domestic owner has more than $50 \%$ of the shares. This is less than half the effect we found when ignoring firm heterogeneity. If all individual domestic owners together have more than $50 \%$ of the shares, an increase in the net tax benefit of debt by 10 percentage points leads to an increase in debt ratios by 0.05 percentage points and thus becomes negligible.

The remainder of this paper is organized as follows: In section 2 we present the model of the net tax benefit of debt used in the analysis, derive the hypothesis and describe the institutional background. Our data set and descriptive statistics are shown in section 3. Results of our regression analysis are presented in section 4, robustness checks are conducted in section 5. Section 6 concludes. 


\section{Net Tax Benefit of Debt and Institutional Background}

\subsection{Calculation of the Net Tax Benefit of Debt}

From a corporate perspective, interest payments for debt are tax-deductible and create an interest tax-shield while payments to equity investors are not deductible. As a result, debt becomes more attractive compared to equity. This relationship does not necessarily hold if investor level taxes are taken into account. Investor level taxes might cause a so called personal tax penalty, i.e., if dividend payments and/or capital gains received by the owners of the firm are taxed at lower tax rates than interest payments. Gordon / MacKie-Mason (1990) derive a model of the net tax benefit of debt that includes investor level taxes as well as the payout policy of the firm. In this model, if a firm adds an extra dollar of debt, its owners receive $\left(1-\tau_{i}\right) \$$ of the interest payments. In contrast, if a firm decides to raise an additional dollar of equity, its owners receive $\left(1-\tau_{c}\right) \cdot\left(1-\tau_{e}\right) \$$ of the profits, where $\tau_{e}$ is the tax rate on income from equity. Equity can be distributed to owners either as dividend payments or as share repurchases and therefore the tax rate on equity income $\left(\tau_{e}\right)$ can be further decomposed to $\tau_{e}=d \cdot \tau_{d}+(1-d) \cdot \alpha \tau_{g}$, where $d$ is the firm-specific dividend payout ratio, $\alpha$ is a discount factor described below and $\tau_{d}$ and $\tau_{g}$ are the owner-level tax rates on dividends and capital gains.

The taxation of dividends and capital gains differ as capital gains are usually taxed upon realization whereas dividends are taxed upon distribution. In most countries, capital gains are taxed at tax rates that are different from ordinary income, and several countries do not tax capital gains, or tax them at a reduced rate, if some preconditions (minimum thresholds, holding periods) are met. In general, this causes difficulties in determining investor-specific marginal tax rates on capital gains. All our sample countries apply a constant marginal tax rate for capital gains and capital gains are taxed regardless of minimum thresholds or holding periods. We are therefore able to use the statutory marginal tax rate on capital gains and do not need to adjust for investor- or transactionspecific factors.

Firms that are most likely to be affected by changes in capital gains taxation are growth firms which provide the majority of returns to investors via retained earnings and capital gains. Typically, transition economies face high rates of economic growth (see Iradian (2007)). This highlights the importance of considering the payout ratio and taxation of capital gains when analyzing capital structure choices in CEE. One important aspect of 
capital gains taxation is that owners can defer the capital gains tax payment by extending the holding period or completely avoiding capital gains taxation by not selling the shares until death; this causes a distortional effect known as the lock-in effect of capital gains taxation (see Holt/Shelton (1961) and Sprinkel/West (1962)). In order to consider an owner's ability to defer capital gains taxation, we use an effective capital gains tax rate rather than the statutory marginal tax rate on capital gains in our model. In line with Feldstein / Summers (1979), Gordon / McKie-Mason (1990) and Graham (1999) we use the term $\alpha$ to account for the discounting effect and calculate the effective capital gains tax rate as $\tau_{g}^{e f f}=\alpha \cdot \tau_{g}$. Feldstein / Summers (1979) argue that the taxation upon realization as well as the possible deferral of the realization to the future each halve the effective tax rate on capital gains. Therefore, $\alpha$ is assumed to be 0.25 . Due to the current low interest level, we use a more recent estimation of $\alpha=0.5$ and vary the level of $\alpha$ in our robustness checks. In our model, if dividends and capital gains are taxed at the same statutory marginal tax rates, the effective tax rate on capital gains is lower because of the discounting effect of $\alpha$.

The net tax benefit of debt (NTBD) according to Gordon / MacKie-Mason (1990) is calculated as

$$
N T B D=\left(1-\tau_{i}\right)-\left(1-\tau_{c}\right)\left(1-\left(d \tau_{d}+(1-d) \alpha \tau_{g}\right)\right)
$$

The higher the net tax benefit of debt, the higher the expected debt ratio of the firm. Our first hypothesis therefore reads as follows:

\section{Hypothesis 1: The higher the firm-specific net tax benefit of debt $N T B D$ the higher the debt ratio of the firm.}

Taking investor-level taxation into account, debt becomes more attractive the higher the investor-level tax rate on capital gains and/or dividends. This is because income from equity becomes less attractive when taxed at a higher tax rate and owners thus demand a higher pre-tax return.

We calculate the net tax benefit of debt according to equation (1) using the statutory 
marginal tax rates on dividends and capital gains of individual domestic owners 1 In doing so, we implicitly assume that the marginal owner of the firm is an individual domestic owner. For other types of marginal owners, such as foreign individuals or domestic corporate owners, we would have to consider other tax rates. As an example, the net tax benefit of debt would be zero for a corporate owner that can receive tax-free dividends and capital gains from other corporations, whereas interest payments are taxed at the corporate tax rate: $N T B D=\left(1-\tau_{c}\right)-\left(1-\tau_{c}\right)=0$. Since we can observe the ownership structure of the firm, we are able to test whether the assumption that the marginal owner is a domestic individual holds. We can also see how the effect of the net tax benefit of debt on debt ratios changes if we vary the definition of the marginal owner. Not all firms in our sample are fully owned by individual domestic owners, so we can observe firm heterogeneity with respect to the marginal owner. We test whether the assumption that the marginal owner is an individual domestic owner has an influence on the effect of the net tax benefit of debt on the capital structure choice. Our second hypothesis reads as follows:

Hypothesis 2: The effect of the firm-specific net tax benefit of debt, NTBD, on the debt ratio of the firm is higher if the marginal owner of the firm is an individual domestic owner rather than a non-individual domestic owner.

Differentiating NTBD with respect to the payout ratio $d$ yields:

$$
\frac{\partial N T B D}{\partial d}=\left(1-\tau_{c}\right)\left(\tau_{d}-\alpha \tau_{g}\right) \gtreqless 0
$$

This partial derivative does not have a unique algebraic sign, because the statutory tax rates on dividends and capital gains often differ, and because capital gains are taxed upon (deferred) realization. Although the direction is not specified, the dividend payout ratio affects the net tax benefit of debt. We therefore do not formulate a direct hypothesis, but include firm-specific payout ratios into our analysis.

\subsection{Institutional Background}

For our analysis we examine 13 CEE-countries (Bulgaria, Croatia, Czech Republic, Estonia, Hungary, Latvia, Lithuania, Poland, Romania, Russia, Slovakia, Slovenia and

1 Due to the lack of information about the tax status of foreign owners, we focus on individual domestic investors only. Babbel et al. (2015) calculate the net tax benefit of debt for different owner types (i.e., foreign owners, corporate owners) using specific tax rates per owner type. 
Ukraine). For each country we collect information on the corporate tax rate as well as the tax rates on interest, dividends and capital gains for individual domestic owners over the observation period 2002-2012 using the European Tax Handbooks provided by the IBFD. The range of tax rates over the observation period is depicted in Table 1 .

\{Insert Table 1 about here. $\}$

All our sample countries, except for Croatia, Estonia and Lithuania, have changed all tax rates used in our model at least once during the observation period. This substantial variation in tax rates creates an ideal setting that can be exploited by our analysis. During the observation period from 2002 to 2012, 11 out of the 13 countries changed their corporate tax rate (29 changes in corporate tax rates altogether). At the investor level most changes occurred in the taxation of capital gains (22 changes in capital gains tax rates in 11 out of the 13 countries). We also observe 22 changes in dividend tax rates; only the dividend tax rate in the Czech Republic remained unchanged over the observation period. We find taxation of interest income to have the lowest variance in tax rates. We identify 19 changes in interest tax rates during the observation period within 10 different countries. By investigating investor level tax rates we are able to show that it is important to consider firm-specific payout policy when calculating the net tax benefit of debt. The importance of considering firm-specific payout policy is reduced if countries tax dividend payments at the same tax rate as capital gains as shown in section 2.1. In our sample, in 69 out of 143 country-years (48.25\%) dividends are taxed at a different rate than capital gains..$^{2}$

Using the tax rates depicted in Table 1, we calculate country- and year-specific net tax benefits of debt. At this stage, instead of using firm-specific payout ratios, we assume $d$ to account for 0.5 and $\alpha$ to account for 0.5. Our results are shown in Table 2 .

$$
\text { Insert Table } 2 \text { about here. }\}
$$

In Table 2 we show that integrating investor taxes into the calculation of the net tax benefit of debt can cause a personal tax penalty, resulting in an overall negative net tax benefit of debt. Estonia has a negative net tax benefit of debt over the whole observation period. This is due to the fact that in Estonia corporate profits are not taxable until they are

2 This number is in line with data on international tax rates, e.g. Jacob / Jacob (2014) have shown that 11 of 25 countries applied different tax rates on dividends and capital gains in 2008 . 
distributed to owners, therefore $\tau_{c}=0$. In addition, investor level tax rates are identical for interest income, dividends and capital gains. In our model, the effective tax rate on capital gains is lower than the statutory tax rate on capital gains due to $\alpha<1$, so that payments to equity holders are beneficial to payments to debt holders when considering investor level taxes. We also find a negative net tax advantage of debt in Latvia during the years 2003-2009, in Slovakia during the years 2002-2003 and in Slovenia during the years 2002-2005.

\section{Data and Regression Model}

\subsection{Data and Summary Statistics}

We use annual versions of the Amadeus database from Bureau van Dijk to obtain annual firm-level data (financial reports and ownership information). We choose an observation period from 2002 to 2012 since we cannot access ownership data from earlier and later periods. In Table 3, we summarize the sample generation process.

\{Insert Table 3 about here. $\}$

We start our sample generation process with 16,510 firms from 13 CEE-countries with available financial reports for at least one year in the Amadeus database. We then track these firms over the years 2002-2012 and drop observations for which we cannot calculate the firm-specific net tax benefit of debt due to missing observations for the payout ratio. In addition, we drop firms with no or incomplete ownership information.3 Our sample, including basic accounting and complete ownership information, consists of 44,924 firmyear observations and 10,983 firms.

We measure the capital structure of our sample firms using the book debt to total assets ratio. Book debt is calculated as the sum of current and non-current liabilities in Amadeus. 4 To account for firm-specific payout policy and the interaction of firm-specific payout policy and investor level taxes, we include $d$, the firm-specific dividend payout,

3 We define firms with incomplete ownership information as firm where the sum of the percentage of all owner blocks does not add up to at least $99 \%$.

4 The same measure is used by several previous studies, e.g. Overesch/Voeller (2010) and Pfaffermayr et al. (2013). 
into the calculation of the net tax benefit of debt. As we have non-listed firms in the sample we can not observe dividend payments directly from the database. Instead, we calculate the firm-specific dividend payout ratio as a function of the firms' profit/loss per period, Profit, and total shareholder funds, $S F$, as follows:

$$
d_{i, t}= \begin{cases}0 & \text { if } \text { Profit }_{i, t} \leq 0 \\ 1 & \text { if } \quad \text { Profit }_{i, t}>0 \\ & \text { and } \quad S F_{i, t}-S F_{i, t-1} \leq 0 \\ 0 & \text { if } 0<\text { Profit }_{i, t} \leq S F_{i, t}-S F_{i, t-1} \\ \frac{\text { Profit }_{i, t}-\left(S F_{i, t}-S F_{i, t-1}\right)}{\text { Profitit, }} & \text { otherwise. }\end{cases}
$$

According to equation (3), values for $d$ vary between 0 (no profits distributed as dividends) and 1 (all profits distributed as dividends). If the increase in shareholder funds from $t-1$ to $t$ is larger than the observed profit in $t$ we assume that all profits have been retained. In this case, the observed additional increase in shareholder funds must be due to a change in reserves that cannot be observed separately from retained earnings shared in the database 5

Using the firm-specific dividend payout ratio and tax rates from Table 1, we can compute the firm-specific net tax benefit of debt, NTBD as defined in equation (1). In Table 4 we present firm-specific average debt ratios, dividend payout ratios and net tax benefits of debt for all sample firms by year.

\{Insert Table 4 about here. $\}$

We can show that the average debt ratio increases until 2008 and then decreases over the years 2009-2011. During the final year of our observation period, the average debt ratio slightly increases again. 2011 is the year with the lowest average debt ratio $(58.72 \%)$ and 2008 is the year with the highest average debt ratio (73.92\%). The average firm-specific dividend payout ratio of $32.33 \%$ shows that our sample firms do not distribute even a

5 We use different definitions and variations of the firm-specific dividend payout ratio in our robustness tests in section 5 . Some of them address the problem that the Amadeus database does not permit to separately observe changes in reserves. 
third of their profits as dividends. In using only dividend tax rates to account for investor taxes we would thus not cover the majority of the investor level tax burden. Dividend payout ratios also vary over time: from 2005 to 2008 we observe dividend payout ratios below the sample mean, whereas dividend payout ratios in 2009, 2011 and 2012 are found to be above the sample mean $\sqrt{6}$ The average firm-specific net tax benefit of debt accounts for $12.87 \%$. This shows that on average debt financing is preferred to equity financing. Still, the advantage of debt financing has decreased over the years, being highest in the first three years of our sample period (2002-2004).

In Table 5 we show average firm-specific debt ratios, dividend payout ratios and net tax benefits of debt for all sample firms by country.

$$
\text { \{nsert Table } 5 \text { about here. }\}
$$

We find the highest average debt ratio to be for Russian firms with a mean of $74.75 \%$, closely followed by the Ukraine $(74.45 \%)$. The lowest debt ratios can be observed in Estonia (43.97\%) and the Czech Republic (46.54\%). The average debt ratio of Estonian firms is only $58.82 \%$ of the debt ratio for Russian firms, showing a large variation in average debt ratios among countries. This also holds for the average firm-specific payout ratio. The highest average payout ratio, found in Slovakia (41.31\%), is more than twice the value of the lowest payout ratio (Slovenia, 18.06\%). Estonia is the only country with a negative average firm-specific net tax benefit of debt. Also the average net tax benefit of debt in Latvia and Slovakia is close to zero, which means that in these countries tax treatment of debt financing is nearly as preferential as equity financing when considering firm-specific payout policy and investor level taxation.

Our analysis integrates firm level heterogeneity with respect to different ownership structures into the analysis of capital structure choices. Data from Amadeus allows us to categorize owners into the following six groups: foreign, domestic individual, domestic corporate (industrial companies), domestic financial (banks, insurance companies and private equity companies), funds and state. In Table 6 we present average combined holding of these six owner types among the sample countries.

6 These numbers are in line with international data as well as data for listed CEE firms. Over the observation period 2002-2012 the average annual dividend payout ratio of S\&P 500 firms varied between $25 \%$ and $38 \%$. At the same time, the average annual dividend payout ratio of the Stoxx Europe 600 firms was slightly higher, varying between $42 \%$ and $53 \%$. Prior literature analyzing dividend payout ratios of CEE listed firms find average ratios of 30\%, see Lace et al. (2013). 
\{nsert Table 6 about here. $\}$

Individual domestic owners are the largest owner group for all countries. Their combined holding accounts for about $74.69 \%$ of the total ownership. Romania (63.56\%) and Hungary $(67.48 \%)$ are the countries with the lowest combined holding of individual domestic owners. We find high values of combined individual domestic ownership in Latvia (84.43\%) and Poland (81.93\%). Only in 2,245 firm-years (4.99\%) does a firm not have any individual domestic owner, whereas in 15,665 firm-years (34.87\%), the combined holding of individual domestic owners accounts for $100 \%$, meaning that the firm is fully controlled by individual domestic owners. The second most important owner group according to the average combined holding are domestic corporate owners (12.28\%). The average combined holding of foreign investors is $8.83 \%$. It is larger than the combined holding of domestic corporate owners in Estonia, Hungary, Latvia, Lithuania, Poland, Romania, Russia and Slovakia. This shows that foreign owners are nearly as important as domestic corporate owners in our sample countries. Financial owners, funds and the state are only of minor importance in our sample. Although our sample countries are former transition economies, we cannot observe high levels of governmental ownership during our observation period.

In our analysis, we focus on the marginal owner being an individual domestic owner (see hypothesis 2). As suggested by Krämer (2015), not only the largest owner but also the concentration of owners has an influence on the capital structure choice. Jacob et al. (2015) show that the dividend tax sensitivity of owners gradually decreases as the number of owners increases. Therefore, we do not limit our analysis to the largest owner, but also control for the number of owners and ownership concentration applying different definitions of the marginal owner. Our sample firms have on average 2.84 individual domestic owners, the minimum being 0 and the maximum being 222 . In a first step, we define a firm to have an individual domestic marginal owner if the largest individual domestic owner of the firm holds more than $50 \%$ of the shares and is therefore in control of the firm. The variable MOwn 1 is an indicator variable taking the value 1 if the largest individual domestic owner of the firm holds more than $50 \%$ of the shares. Subsequently, we add the share of the second and third largest individual domestic owner to the calculation. We define firms for which the 2 (3) largest individual domestic owners together hold more than $50 \%$ of the shares of a firm as firms with a marginal individual domestic owner and use the indicator variables MOwn12 and MOwn123 in our analysis. In a last step, we define firms, for which the combined holding of all individual domestic owners is above $50 \%$ to have an individual domestic marginal owner ( $M O w n A l l)$. In Table 7 , we show the average percentage of firms with an individual domestic marginal owner. 
\{Insert Table 7 about here.

The percentage of firms with the largest individual domestic owner having more than $50 \%$ of the shares of the firm varies between $31.19 \%$ in Slovakia and $71.61 \%$ in Russia. If we do not only consider the shares of the largest individual domestic owner, but also consider the shares of the second largest individual domestic owner, the percentage of firms with a individual domestic marginal owner increases by about 15 percentage points (from $58.90 \%$ to $73.99 \%$ ). In contrast, considering also the shares of the third largest individual domestic owners only increases the percentage of firms with an individual domestic marginal owner by 2.49 percentage points. If we consider all individual domestic owners for the definition of the marginal owner rather than the three largest individual domestic owners, the increase is only 0.35 percentage points. These numbers reflect the fact that our sample firms on average have only 2.84 individual domestic owners, which is why adding a third individual domestic owner or considering all individual domestic owners does not substantially increase the percentage of firms with an individual domestic marginal owner. As we increase the number of individual domestic owners considered for the definition of the marginal owner, ownership concentration of the firm decreases. Thus, our measures of the marginal owner can also be seen as a proxy for ownership concentration. We will consider the different definitions of the marginal owner in our regression analysis in order to evaluate the effect of ownership on capital structure choice.

\subsection{Regression Model}

We are interested in the combined effects of investor taxation and firm heterogeneity on the capital structure choice of firms. Our dependent variable DebtRatio is defined by the book debt to total assets ratio. In our regressions, we use the following tax as well as firm- and country-level non-tax control variables.

Our main tax variable of interest is the firm-specific net tax benefit of debt, $N T B D$, calculated according to equation (1), using the constant marginal tax rates from Table 17 We calculate $d_{i, t}$, the firm-specific dividend payout ratio, as shown in equation (3).

7 As mentioned before, using CEE countries has one major advantage in calculating tax effects, since constant marginal tax rates apply to all types of income that enter our model and all types of income are fully taxed without further requirements such as minimum thresholds or holding periods. There are only three exceptions from constant marginal tax rates in the sample: in Hungary, Poland and Slovakia capital gains were subject to progressive income tax rates in 2002-2004 (Hungary) and 20022003 (Poland and Slovakia). In this case, we use the top statutory income tax rate to determine $\tau_{g}$. 
Graham (1999) points out that one problem in using firm-specific payout ratios is that payout decisions might be determined simultaneously with capital structure choice. In order to overcome this problem, we follow the approach of Graham (1999) and use a oneyear lagged firm-specific dividend payout ratio for the calculation of the net tax benefit of debt 8 In line with hypothesis 1 , we expect a firm's debt ratio to be higher, the higher the net tax benefit of debt and therefore a positive coefficient for NTBD.

Büttner et al. (2012) show that thin-capitalization rules limit the deductibility of interest payments and therefore negatively affect the debt ratio of a firm. We add the variable Thincap as our second tax control variable to the model. Thincap is a dummy variable taking the value 1 if a thin-capitalization rule exists in a country in the considered year and 0 otherwise. In the sample, only Estonia and Ukraine have no thin-capitalization rules over the entire observation period. Latvia and Romania introduced thin-capitalization rules in 2003, Slovenia followed in 2006. Slovakia repealed its thin-capitalization regulation in 2010. We expect the coefficient of Thincap to be negative.

To test our first hypothesis, we run the following linear regression model,

$$
\operatorname{DebtRatio}_{i, t}=\alpha+\beta_{1} N T B D_{i, t}+\beta_{2} \text { ThinCap }_{t}+\beta X_{i, t}+\beta Y_{t}+u_{i}+v_{t}+\epsilon_{i, t},
$$

where $X$ represents a vector of non-tax firm-level control variables and $Y$ a vector of non-tax country-level control variables.

DeAngelo / Masulis (1980) show that debt ratios of firms are influenced by the existence of tax shields other than interest payments such as depreciation, investment tax credits or loss-carryforwards. Among the non-tax control variables, we implement NOL to control for other possibilities that generate tax-shields (substitution hypothesis). It is a dummy variable taking the value 1 if there is a negative EBIT in the previous year and 0 otherwise. We expect a negative coefficient for NOL.

Previous studies such as Wald (1999) found out that the profitability of a firm has an influence on its debt ratio. There are several theories regarding which direction profitability influences the debt ratio. According to the trade-off theory more profitable firms should have higher debt ratios as there is a lower risk of financial distress, see Kraus / Litzenberger (1973). Also the free cash flow theory suggests that more profitable firms will have

8 We will provide additional ways of dealing with the simultaneous determination of payout policy and capital structure choice in the robustness checks in section 5 . 
higher debt ratios (see Jensen (1986)), while the pecking order theory argues that firms with investment opportunities are more profitable and less levered, see Myers and Majluf (1984). We calculate Profit as the EBIT deflated by total assets, both lagged by one year. To control for size effects, we add Size to our model, measured as the natural logarithm of total assets as suggested by Schulman et al. (1996). Larger corporations are found to have higher debt ratios, which is why we expect a positive coefficient for Size. Additionally, we include Tangibles, tangible assets deflated by total assets, into our regression model. Again, previous literature has found ambiguous effects of tangibles on debt financing. On one hand, the costs of financial distress are expected to be lower, the higher the tangible assets are as they serve as collateral (see Scott (1977) and Harris / Raviv (1990)). On the other hand, following the argumentation of DeAngelo and Masulis (1980), higher tangible assets lead to higher non-debt tax shields related to tangible assets such as depreciation or investment credits that crowd out the positive effect of interest deduction. Pfaffermayr et al. (2013) show that the debt ratio of a firm changes throughout its life-cycle. We therefore add the variable Age, calculated as the natural logarithm of the years between incorporation and the year under investigation, to test whether older firms have smaller debt ratios and we expect a negative coefficient for Age. For Sub controls for the number of foreign subsidiaries and the possibility of debt shifting through foreign subsidiaries, see Huizinga et al. (2008).

To control for time-variant country-specific effects, we add three country-level variables to the model. During our observation period, most of the CEE countries analyzed became EU member states. EU membership offers new opportunities for international financing. $E U$ is a dummy variable taking the value 1 if the country is an EU-member in the current year and 0 otherwise. Ways of financing have been found out to depend on the size of the country's capital market. We control for this effect by integrating Market, calculated as stock market capitalization deflated by the GDP. Another important aspect with respect to debt financing is creditor rights, i.e. law enforcement in the given country. We use the rule of law estimate of the Worldbank, Law, to control for enforcement of creditor rights.

We additionally include firm- and year-fixed effects in our model to control for unobserved time-invariant firm and country heterogeneity.

To test our second hypothesis, we add information on firm heterogeneity with respect to ownership and extend our first regression model by including our different measures of the marginal owner (MOwn) as shown in Table 7. We expect the influence of the firm-specific net tax benefit of debt on the debt ratio to be higher for firms where the marginal owner is an individual domestic owner. Our second linear regression model reads as follows: 


$$
\begin{array}{r}
\text { DebtRatio }_{i, t}=\alpha+\beta_{1} \cdot N T B D_{i, t}+\beta_{2} \cdot \text { ThinCap }_{t}+\beta_{3} \text { MOwn }_{i, t} \\
+\beta_{4} \cdot \text { MOwn }_{i, t} \cdot N T B D_{i, t}+\beta X_{i, t}+\beta Y_{t}+u_{i}+v_{t}+\epsilon_{i, t}
\end{array}
$$

In our second regression model we expect a positive coefficient for the interaction term $M O w n_{i, t} \cdot N T B D_{i, t}$. We also expect the coefficient to be highest if we only consider the share of the largest individual domestic owner, $M O w n 1_{i, t}$, for the definition of the marginal owner and to decrease as we consider the shares of more owners in our definition. As we add more owners to our definition, ownership of the firms becomes more dispersed; this leads to a lowering of the effect of $M O w n_{i, t} \cdot N T B D_{i, t}$ on the debt ratio. In our second regression model, we use the same set of non-tax control variables and fixed effects as in our first regression model.

Table 8 shows summary statistics for all control variables included in our regression analysis.

\{Insert Table 8 about here. $\}$

The mean of ThinCap is $91.38 \%$, showing that nearly all of the countries in our sample apply thin-capitalization rules in order to limit the deductibility of interest payments. Controlling for the substitution hypothesis we identify only $17.81 \%$ of our observations to have a tax-loss-carryforward. Although we observe a low number of loss-firms, the average profitability is also low, accounting for only $4.81 \%$. The oldest firm in the sample is 301 years old, but the average value (31.37 years) is far below.

\section{The Effect of Individual Taxes and Firm Heterogeneity on Capital Structure Choice}

We start our empirical analysis by integrating investor level taxation into the calculation of the net tax advantage of debt, but ignoring firm heterogeneity (ownership and payout policy, see Overesch/Voeller (2010)). By ignoring the firm-specific payout policy, we assume that all profits are distributed to owners as dividends (i.e., $d=1$ ) and accordingly,

$$
N T B D=\left(1-\tau_{i}\right)-\left(1-\tau_{c}\right) \cdot\left(1-\tau_{d}\right)
$$


In Table 9 we present results for the influence of the net tax benefit of debt, calculated considering investor-level taxes, on debt ratios:

\{Insert Table 9 about here.

Column (1) in Table 9 gives the results considering investor level taxation, but ignores payout policy and ownership of the firm. We obtain a significant positive coefficient for the net tax benefit of debt, $N T B D$, of 0.2497 . An increase in the net tax benefit of debt by 10 percentage points leads to an increase in the debt ratio of about 2.49 percentage points ${ }^{9}$ We do not find significant results for our second tax variable ThinCap and attribute the lack of significance to two reasons. Firstly we only use a dummy variable controlling for the existence of a thin capitalization rule and are not able to observe whether our sample firms are affected by the thin capitalization rule. Secondly, most of the countries do not show any variance in regulations with respect to thin capitalization rules, as shown in section 3.2. Among our firm-level control variables, we find significant positive effects for $N O L$, Size and Age and significant negative effects for Profit and Tangibles. According to the substitution hypothesis, loss-carryforwards serve as an additional tax-shield that lower the tax effect of interest deductibility, which is why we would expect a negative coefficient for NOL. However, the value of other tax shields also depends on the corporate tax rate in the country. We therefore multiply $N O L$ by the statutory corporate tax rate, $\tau_{c}$, and include the interaction term in our regression analysis. Non-tabulated results show that the coefficient for the interaction term (significant at the 1\% level) is now negative and accounts for -0.1928 , in line with our expectation.

In column (2) we integrate firm heterogeneity with respect to ownership into the regression analysis, and still do not consider firm-specific payout policy. If the largest individual domestic owner has more than $50 \%$ of the firm's shares we define the firm to have an individual domestic marginal owner $(M O w n 1=1)$. To control for the presence of an individual domestic marginal owner, we include the variable MOwn1 as well as the interaction term of MOwn1 and NTBD into the analysis. We obtain a significant negative coefficient for MOwn1, accounting for -0.0406 . If the largest individual domestic owner owns more than $50 \%$ of the firm's shares, debt ratios are on average 4 percentage points lower than if the largest individual domestic owner is not the marginal owner. The coefficient of the interaction term $M O w n 1 \cdot N T B D$ is significant and has the expected positive

9 In comparison, the coefficient of Overesch/Voeller (2010), based on a sample of European countries, is 0.2870 , showing that the effects found for CEE countries do not differ substantially from other European countries. 
sign. The combined effect of the net tax benefit of debt on debt ratios accounts for 0.2679 $(=-0.0128+0.2807)$ if the firm's marginal owner is an individual domestic owner. In contrast, if the largest individual domestic owner is not the marginal owner, the effect of the net tax benefit of debt is negative $(-0.0128)$ and no longer significant. Controlling for firm-specific ownership increases the effect of the net tax benefit of debt on debt ratios from 0.2497 to 0.2679 if the firm's marginal owner is an individual domestic owner. In addition, we are able to show that there is no significant effect of the net tax benefit of debt on debt ratios for firms if the largest individual domestic owner is not the marginal owner. As soon as the largest individual domestic owner is not the marginal owner, the effect becomes negative and insignificant, showing that results in column (1) have been solely driven by firms for which the largest individual domestic owner is the marginal owner.

In column (3) we do not use the net tax benefit of debt as our main tax variable, but estimate separate effects for the tax rates on corporate $\left(\tau_{c}\right)$, interest $\left(\tau_{i}\right)$, dividend $\left(\tau_{d}\right)$ income as well as taxes on capital gains $\left(\tau_{g}\right)$. Results show a significant positive effect of the corporate tax rate as well as the dividend tax rate on debt ratios and a significant negative effect of the interest tax rate on debt ratios. The coefficient for the tax rate on capital gains is negative, but not significant. Our results show that an increase in the corporate tax rate (dividend tax rate) by 10 percentage points increases debt ratios by about 2.1 (3.7) percentage points, holding other tax rates constant. Again, these results are in line with the results of Overesch/Voeller (2010).

Controlling for firm-specific ownership is crucial for the effect of the net tax benefit of debt on capital structure choice. In a second step, we integrate the second source of firm heterogeneity (firm-specific payout policy) into our analysis. Only the fraction of profits that are paid out as dividends are subject to dividend tax rates, whereas retained earnings generate future capital gains, thus triggering capital gains taxation. Our results for the estimation of the influence of $N T B D$ on debt ratios, calculated according to equation (1), are presented in Table 10 .

\{Insert Table 10 about here. $\}$

We have shown in Table 4 that only about $32.33 \%$ of all profits are distributed to shareholders as dividends, whereas the rest is retained and therefore subject to capital gains taxation in the future. In our model of the net tax benefit of debt we use the effective capital gains tax rate, obtained by multiplying the statutory capital gains tax rate with a discount factor $\alpha$, in order to reflect the fact that capital gains taxation is deferred until 
the realization of the gain in the future ${ }^{10}$ Low firm-specific dividend payout ratios as well as effective capital gains tax rates that are lower than dividend tax rates both lead to a reduction in the tax rate on income from equity. As taxation of equity decreases, the net tax advantage of debt also decreases. We therefore still expect a positive, but compared to column (1) in Table 9, a lower coefficient for $N T B D$ if we integrate firm-specific payout policy into the analysis. Results shown in column (4) in Table 10 support our expectations. The coefficient for NTBD is significantly positive, but accounts for only 0.0942 . This means, that an increase in the firm-specific net tax benefit of debt by 10 percentage points leads to an increase in the debt ratio of 0.94 percentage points if we consider firmspecific payout policy. This is only about a third of the coefficient for NTBD we found in column (1) in Table 9 (0.2497) and reflects the observed mean dividend payout ratio of about $32.33 \%$. Again, we do not find significant results for ThinCap and attribute this to the same reasons as in Table 9 .

In column (5) we present the results of the final model, including investor level taxation and both sources of firm heterogeneity, payout policy and ownership structure. We find a significant positive coefficient for the interaction term $M O w n 1 \cdot N T B D$ of 0.2389 and a significant negative coefficient for $N T B D$ of -0.1122 , resulting in a combined effect of $0.1267(=0.2389-0.1122)$ if the firm's largest individual domestic owner is the marginal owner. This is less than half of the effect found in column (1) in Table 9 in which we included investor level taxes, but did not consider firm heterogeneity. Our results show that ignoring firm heterogeneity leads to a substantial overestimation of the effect of investor level taxes on capital structure choice. Again, if the largest individual domestic owner is not the marginal owner, we observe a negative effect of the net tax benefit of debt on debt ratios of firms.

So far, our definition of the marginal owner required a firm to have one individual domestic owner holding more than $50 \%$ of the shares of the firm. Next, we investigate whether different definitions of the marginal owner affect the impact of taxes on capital structure choice. As ownership becomes less concentrated, conflicts between owners as described by Shleifer / Vishny (1986) arise. On one hand, as the number of owners increases, divergence of interests of the different owners also increases, management becomes more difficult to monitor and free rider problems with respect to monitoring arise. We therefore expect the influence of the net tax benefit of debt to decrease with ownership dispersion. In particular, we analyze the effect on firms for which the combined shares of the two (three)

10 Among our sample countries we find lower tax rates on dividends than on capital gains for only 35 out of 143 country-year observations $(24.48 \%)$. 
largest individual domestic owners account for more than $50 \%$ of the total ownership (MOwn12 and MOwn123). In addition, we separate effects for firms if the combined share of all individual domestic owners is above $50 \%$ ( $M O w n A l l)$. Although we still expect positive effects for MOwn12, MOwn123 and MOwnAll, we also expect the coefficients to decrease as ownership dispersion increases.

In Table 11 we show results for the different definitions of the marginal owner.

\{Insert Table 11 about here. $\}$

We first discuss the results obtained without integrating firm-specific payout ratios into the calculation of the net tax benefit of debt (see equation (6)), as shown in columns (1) to (3) in Table 11. In column (1) we show that the combined effect of the net tax benefit of debt on debt ratios is positive and significant if the firm's two largest individual domestic owners together hold more than $50 \%$ of the shares. The combined effects accounts for $0.1855(=-0.0065+0.1920)$. In column $(3)$ in Table 9 we identify a combined effect of the net tax benefit of debt on debt ratios of 0.2679 if the largest individual domestic owner has more than $50 \%$ of the shares. Comparing the two effects, we find the expected reduction in the magnitude of the effect once the number of individual owners increases and thus ownership concentration decreases. Moving from two owners to three owners further reduces the coefficient to $0.1729(=0.0150+0.1579)$ as shown in column $(2)$. Finally, looking at firms for which the combined share of all individual domestic owners is above $50 \%$, shows the lowest coefficient of $0.1720(=0.0145+0.1575)$, see column (3). This coefficient is the lower bound of the effect of the net tax benefit of debt on firm's capital structure choice if the firm's marginal owner is an individual domestic owner. Considering different firm-specific ownership structures, the total effect of the net tax benefit of debt on debt ratios varies between $[0.2679 ; 0.1720]$. Depending on the ownership structure of the firm, the effect of taxes on capital structure choice for concentrated ownership is more than $150 \%$ of the effect for dispersed ownership. This corresponds to the findings of Krämer (2015). In all specifications, the coefficient for NTBD is close to zero and not significant, inidcating that there is no effect of the net tax benefit of debt on debt ratios for firms if the marginal owner is not an individual domestic owner.

In columns (4) to (6) in Table 11 we present results for the same definitions of the marginal owner, but now considering firm-specific payout ratios when calculating the net tax benefit of debt (see equation (1)). Again, we can observe that the combined effect of the net tax benefit of debt decreases as the number of individual domestic owners increases. If the two largest individual domestic owners of the firm together have a share of more than 
$50 \%$, the effect accounts for $0.0695(=-0.1457+0.2152)$ in column $(4)$, compared to 0.1267 in column (6) in Table 10. Considering the combined share of the three largest individual domestic owners the effect drops to $0.0582(=-0.1323+0.1905)$ in column $(5)$. A lower bound of the effect is again represented by firms for which the combined share of all individual domestic owners is above $50 \%$. For these firms, the effect accounts for $0.0586(=-0.1372+0.1958)$. When considering firm-specific payout policy and ownership structure, we find a higher variance for the effect of the net tax benefit of debt on debt ratios, the coefficient taking values between 0.1267 and 0.0582 .

So far, we have used the combined shares of the largest and the two (three) largest individual domestic owners in order to define the marginal owner of a firm. Alternatively, we use an incremental definition of the marginal owner as follows: MOwn 1 takes the value 1 for firms for which the share of the largest individual domestic owner is above $50 \%$. MOwn 2 takes the value 1 if the share of the two largest individual domestic owner is above $50 \%$, but only if $M O w n 1=0$. MOwn 2 can therefore be calculated as MOwn12-MOwn1. Accordingly, MOwn3 takes the value 1 if the share of the three largest individual domestic owner is above $50 \%$, but only if MOwn $1=0$ and MOwn $2=0$ and MOwnAllincre takes the value 1 for all firms for which only the combined share of more than the three largest individual domestic owner is above 50\%. In using an incremental definition of the marginal owner we can analyze whether the effect of the net tax benefit of debt on debt ratios is significantly altered as the number of individual domestic owners per firm increases. In Table 12 we show results for an incremental definition of the marginal owner.

\{Insert Table 12 about here.

Our results obtained when using an incremental definition of the marginal owner again show a significant effect of the net tax benefit of debt on debt ratios only for firms for which the share of the largest individual domestic owner is above $50 \%$. When the majority of shares is not held by one single domestic individual owner, we cannot find a significant effect of the net tax benefit of debt on the debt ratio of the firm.

\section{Robustness Tests}

Our main results in Table 10 show that integrating firm-specific payout policy reduces the effect of the net tax benefit of debt on debt ratios. As shown in section 2.1, the combined owner-level tax rate on equity income is determined by both the taxation of 
dividends and capital gains. Whereas dividends are taxed upon distribution, capital gains are taxed at realization, offering owners the possibility to defer capital gains taxation. In our calculations of the net tax benefit of debt, we therefore use an effective capital gains tax rate rather than the statutory marginal tax rate on capital gains and multiply the statutory marginal tax rate on capital gains by $\alpha=0.5$. In order to test whether our results are influenced by the choice of $\alpha$ we re-calculate $N T B D$, assuming that $\alpha=0.25$ as suggested by Feldstein / Summers (1979). Also, we ignore the benefit arising from the deferral of capital gains taxation and re-calculate NTBD assuming that $\alpha=1$. Our results for the estimation of the influence of $N T B D$ on debt ratios following equations (4) and (5) are presented in Table 13.

\{Insert Table 13 about here.

Considering different definitions of the capital gains tax discount factor $\alpha$ and different definitions of the marginal owner of the firm, we find results similar to our main findings in tables 10 to 12 . If we lower $\alpha$ to 0.25 , we still find a positive and significant combined effect of the net tax benefit of debt on debt ratios of $0.1238(=0.2081-0.0843)$ if the largest individual domestic owner of the firm has more than $50 \%$ of the shares of the firm. By contrast, if we do not consider a discounting factor, assuming that investors do not defer the realization of capital gains, the combined effect is still positive and significant, but drops to $0.0991(=0.1982-0.0991)$. As in Tables 10 to 12 , the combined effect is smaller if we consider firms for which the combined share of all individual domestic owners is above $50 \%$ for both definitions of $\alpha$, although the reduction is less prominent for lower values of $\alpha$. Different definitions of $\alpha$ support our main result that considering firm-specific payout policy lowers the effect of the net tax benefit of debt on debt ratios.

Integrating the firm-specific payout policy into the calculation of the net tax benefit of debt raises the problem that the dividend policy of the firm might be simultaneously determined with debt policy. So far, we have followed the argumentation of Graham (1999) and have used the firm-specific payout policy lagged by one year for the calculation of the net tax benefit of debt. We now present five alternative measures for the firmspecific payout policy in order to see whether our main results still hold. In particular, we use a three-years moving average of the firm-specific dividend payout ratio, an average dividend payout ratio based on country-years and the naive assumption that $d=0.5$. Additionally, we re-calculate the firm-specific dividend payout ratio as defined in equation (3), using an alternative definition of shareholder funds. In Amadeus, total shareholder funds are further split into two items: subscribed capital and other shareholder funds. 
In equation (3) we used total shareholder funds for our calculation of the firm-specific dividend payout ratio. In order to test whether our calculations are influenced by changes in subscribed capital rather than retained earnings, we only use other shareholder funds (retained earnings and reserves) and re-calculate equation (3). In a last specification, we calculate a firm-specific average dividend payout ratio as follows: ${ }^{11}$

$$
\frac{\sum_{t=1}^{T} \operatorname{Profit}_{i, t}-\left(S F_{i, T}-S F_{i, 0}\right)}{\sum_{t=1}^{T} \operatorname{Profit}_{i, t}}
$$

If we consider the sum of profits rather then single-year observations of a firm's profit, we are able to calculate firm-average payout ratios including years with negative profits.

In Table 14, we present results for $N T B D$ and the interaction term NTBD MOwn for different definitions of the marginal owner. Still, we focus on individual domestic marginal owners and do not calculate $N T B D$ for other types of marginal owners such as domestic corporate or foreign owners. If the marginal owner is an individual domestic owner, the upper bound for $N T B D$ is represented by firms for which the largest individual domestic owner has more than $50 \%$ of the shares and the lower bound is represented by firms for which only all individual domestic owners together have more than $50 \%$ of the shares.

\{Insert Table 14 about here.

In column (1) in Table 14 we use the firm-specific three-years moving average of the payout ratio instead of the firm-specific dividend payout ratio lagged by one year in order to calculate the net tax benefit of debt 12 The mean of NTBD, calculated using $\alpha=0.5$, is 0.1271 , compared to 0.1287 if we consider the payout ratio of the last year. Our estimation results in column (1) show significant positive results for the interaction term of the net tax benefit of debt and the marginal owner on capital structure choice and a combined effect of 0.1072 if all individual domestic owners of the firm together have more than $50 \%$ of the shares. Compared to the results in Table 11, the combined effect is smaller than the effect we found without consideration of firm-level payout policy (0.1720), but larger

11 If the firm-specific average dividend payout ratio is negative, we assume a payout ratio of 0 and if the firm-specific average dividend payout ratio is above 1, we assume a payout ratio of 1 .

12 This reduces our sample size by 660 firm-year observations, since we are not able to compute a threeyears average for the year 2002 due to missing data for years prior to 2000 . 
than the effect we found when integrating firm-level payout policy (0.0582). In line with our main results from Section 4 we find the combined effect of the net tax benefit of debt to decrease as ownership concentration of individual domestic owners decreases. If the largest individual domestic owner of a firm has more than $50 \%$ of the shares, the effect of the net tax benefit of debt on debt ratios is about twice the effect than if all individual domestic owners together have more than $50 \%$ of the shares. This result also holds if we use country-year average dividend payout ratios (column (2)), or assume that firms pay half of their profits as dividends (column (3)).

Results for two alternative firm-specific calculations of dividend payout ratio are shown in column (4) and (5) in Table 14. In column (4) we do not include subscribed capital as part of shareholder funds into the calculation of the firm-specific dividend payout ratio. This raises the mean of the firm-specific net tax benefit of debt from 0.1287 to 0.1310 and, consequently, the influence of the net tax benefit of debt on debt ratios. If the largest individual domestic owner is the marginal owner of the firm, we find a combined effect of 0.1855 , compared to 0.1267 in column (3) in Table 10. Again, this effect is more than twice the effect than if all individual domestic owners together have more than $50 \%$ of the shares. In column (5) we calculate a firm-specific average dividend payout ratio over the whole observation period per firm. Again, this slightly raises the mean of the net tax benefit of debt from 0.1287 to 0.1335 and also the combined effect of the net tax benefit of tax on debt ratios if the largest individual domestic owner is the marginal owner to 0.1364 .

Throughout our robustness checks the effects obtained when integrating firm-specific payout policy into the calculation of the net tax benefit of debt are lower than the effects obtained without considering firm-specific payout policy, although the magnitude of the effects varies with respect to the calculation of firm-specific payout policy. Still, we are able to show that neglecting payout policy while integrating investor level taxes, leads to an overestimation of the effect of the firm-specific net tax benefit of debt on payout policy. In addition, we can show that considering firm-specific ownership structure helps to reduce the problem of overestimating tax effects when not considering firm-specific payout policy.

Russian firms make up about $44 \%$ of all our sample companies and show the highest average debt ratio among all sample countries. We therefore repeat our main regression analysis and exclude 19,862 firm-year observations for Russian firms from our sample. The results without Russian firms are shown in Table 15.

\{Insert Table 15 about here. $\}$ 
Excluding Russian firms from the sample reduces the combined effect of the net tax benefit of debt on debt ratios for all definitions of the marginal owner if we use firm-specific payout ratios. For the first time, we observe a combined negative effect if we consider only firms for which the combined holding of all individual domestic owners together is larger than $50 \%$. Non-tabulated results show that we also find a negative combined effect when the three largest individual domestic owners together have more than $50 \%$ of the shares. In contrast, we find significant positive combined effects if the largest individual domestic owner has more than $50 \%$ of the shares (0.0389) and also if the two largest individual domestic owners together have more than $50 \%$ of the shares (0.0013). For more than two individual domestic owners, including investor-level taxes no longer shows the expected positive effect of the net tax benefit of debt on debt ratios.

In another robustness test we address the problem of calculating firm-specific payout ratios for years in which the increase in shareholder funds from $t-1$ to $t$ is larger than the observed profit in $t$. In this case some changes in shareholder funds must be driven by changes in reserves that cannot be observed directly from our data. So far, we assumed no dividend payments for those years. In our robustness tests, we eliminate all firm-years, for which the increase in shareholder funds from $t-1$ to $t$ is larger than the observed profit in $t$ from the sample. This reduces our sample size to 30,584 firm-year observations and 9,958 firms. The results are shown in Table 16.

\section{\{Insert Table 16 about here.}

For years in which the change in shareholder funds is larger than the observed positive profit, we have so far assumed that all profits have been retained and the additional increase in shareholder funds is driven by changes in reserves. In our sample, nearly $32 \%$ of all firm-years show changes in shareholder funds that are larger than the observed positive profit. Excluding those years from the analysis raises the average firm-specific dividend payout ratio from 0.3233 to 0.4304 , whereas the average firm-specific net tax benefit of debt rises only marginally from 0.1287 to 0.1327 . In our regression analysis, we observe similar combined effects if the largest individual domestic owner of a firm has more than $50 \%$ of the shares. In this case, the combined effect of the net tax benefit of debt on debt ratios account for 0.1124, compared to 0.1267 in Table 10. If all individual domestic owners together have more than $50 \%$ of the shares of the firm, the combined effect is still positive, but smaller than in Table 10, accounting for 0.0169 only.

Throughout our robustness tests we are able to show that the influence of the net tax benefit of debt on debt ratios is lower the higher the number of individual domestic owners 
representing the marginal owner of the firm. When individual domestic owners do not represent the marginal owner of the firm, using investor-level taxes in order to calculate the net tax benefit leads to an expected coefficient that is close to 0. Also in line with our main results, integrating firm-specific payout policy and thus distinguishing between dividends and capital gains is important when using investor-level taxes for the calculation of the net tax benefit of debt. Most of the profits in our sample are not distributed as dividends, but retained and thus resulting in future capital gains of the owners. The discounting effect of deferred realization of capital gains together with different statutory tax rates on dividends and capital gains leads to a reduction of the net tax benefit of debt due to reduced tax rates on equity income.

\section{Conclusion}

Interest payments for debt are tax-deductible at the corporate level, creating an interest tax-shield, while payments to equity investors are not. This causes a tax distortion to firm behavior, as debt becomes relatively more attractive than equity. Following Miller (1977), several papers have shown that not only corporate, but also investor-level taxes have to be considered when measuring the net tax benefit of debt due to the so-called personal tax penalty. In this paper, we add to existing literature by jointly analyzing the influence of investor level taxes and heterogenous ownership structure and payout policy of firms to shed new light on the effect of taxes on capital structure choice.

We follow the definition of the net tax benefit of debt by Gordon / MacKie-Mason (1990) and use data from 13 countries from Central and Eastern Europe over the period 20022012 to test whether higher net tax benefits of debt result in higher debt levels. Contrary to prior research, we can observe firm-specific payout ratios and the complete ownership structure of the firm on a yearly basis. This allows us to identify whether a firm has one (or several) individual domestic marginal owner(s) in a given year and to test the effect of the net tax benefit of debt on debt levels with respect to ownership concentration.

In line with prior research, we find debt ratios in our sample to increase with the net tax benefit of debt. Not considering firm heterogeneity, an increase in the net tax benefit of debt of 10 percentage points leads to an increase in debt ratios of 2.49 percentage points. Contrary to prior research considering owner-level taxes, we add the firm-specific payout policy to the calculation of the net tax benefit of debt. Our sample firms on average distribute only a third of profits as dividends, whereas the rest of the profits are retained and subject to capital gains taxation in the future. We show that not considering 
firm-specific payout policy leads to an overestimation of the net tax benefit of debt that is driven by the discounting effect of deferred realization of capital gains together with different statutory tax rates on dividends and capital gains. When considering firmspecific payout ratios, an increase in the net tax benefit of debt of 10 percentage points leads to an increase in debt ratios of only 0.94 percentage points.

We show that it is important to control for another source of firm heterogeneity when evaluating the effect of investor level taxes on debt ratios: firm-specific ownership. Results for the effect of the net tax benefit of debt on debt ratios crucially depend on the nature of the marginal owner of the firm. We find the effect of the net tax benefit of debt on debt ratios to be highest if the largest individual domestic owner has more than $50 \%$ of the shares of the firm. In this case, an increase in the net tax benefit of debt of 10 percentage points leads to an increase in debt ratios of 1.27 percentage points. The effect is still positive, but decreases if the two or three largest individual domestic owners of the firm together hold more than $50 \%$ of the shares. When the number of owners increases, the effect of the net tax benefit of debt on debt ratios decreases. If the combined holding of all individual domestic owners is above $50 \%$ and individual domestic owners are the largest owner group of the firm, the tax effect on debt is close to zero.

Our results are robust to different measures of the net tax benefit of debt, i.e., different calculations of the payout ratio as well as the effective tax rate on capital gains. Our findings add to prior literature by providing a more precise measure of the effect of investor level taxes on capital structure choice. We can show that it is important to consider the interplay of the two sources of firm heterogeneity (ownership and payout policy), rather than separately controlling for them and that ignoring firm heterogeneity leads to a severe overestimation of tax effects. Using owner-specific tax rates that are based on firm-specific ownership information is crucial in determining the effect of taxes on debt ratios, especially if firm-specific ownership shows a high level of dispersion and marginal owners belong to different owner types.

Of course, our study is subject to several limitations. Data restrictions, such as measurement of the payout ratio, are due to data availability in the relevant databases and can only be avoided by hand-collecting prohibitively large numbers of financial statements. For similar reasons, hybrid financial instruments that can be qualified either as debt or equity cannot always be properly identified. Moreover, the qualification of provisions as debt is ambiguous across jurisdictions. Although we have detailed annual ownership data, we cannot observe whether or not share capital and voting rights are equivalent. It is therefore possible that preferential voting rights enable minority shareholders to dominate 
a corporation and to enforce their favorite debt policy. Furthermore, tax rulings such as tax holidays for particular investors can distort the net tax benefit of debt. Since tax rulings are not publicly observable ${ }^{13}$ our study relies solely upon statutory corporate and individual tax rates.

There are several interesting avenues for future research regarding ownership and capital structure. Apart from industry-related effects, a related test could be whether firms that were subject to major ownership changes also changed their capital structure and dividend policy. Such a result seems especially likely in cases of leveraged buyouts or management buyouts. Moreover, the impact of the tax sensitivity of leading individual shareholders on capital structure could be investigated in more detail by use of data from reported insider trades. However, this is only feasible for listed corporations, a small minority of all enterprises in Europe. For a more comprehensive view of corporate debt policy, it would be desirable to include leasing as a substitute for debt in our analysis. This extension, however, would require a detailed analysis of IFRS financial statements that are typically unavailable in databases. Similar data restrictions apply for hybrid financing that can be used as a device for tax avoidance.

13 The so-called LuxLeaks are an example for involuntary publication of confidential tax data such as tax rulings. See International Consortium of Investigative Journalists (2016). 


\section{References}

Babbel, Michael / Hundsdoerfer, Jochen / Pronobis, Paul (2015): Tax Preference Heterogeneity and Capital Structures, Working Paper.

Baxter, Nevins D. (1967): Leverage, Risk of Run and the Cost of Capital, in: Journal of Finance 22, p. 395-403.

Berk, Ales (2006): Determinants of Leverage in Slovenian Blue-Chip Firms and Stock Performance Following Substantial Debt Increases, in: Post-Communist Economies 18, p. 479-494.

Büttner, Thiess / Overesch, Michael / Schreiber, Ulrich / Wamser, Georg (2012): The Impact of Thin-Capitalization Rules on the Capital Structure of Multinational Firms, in: Journal of Public Economics 96, p. 930-938.

Cloyd, Bryan C. / Limberg, Stephen T. / Robinson, John R. (1997): The Impact of Federal Taxes on the Use of Debt by Closely Held Corporations, in: National Tax Journal 50, p. 261-277.

Dhaliwal, Dan / Trezevant, Robert / Wang, Shiing-wu (1992): Taxes, Investment-Related Tax Shields and Capital Structure, in: Journal of the American Taxation Association 14, p. $1-21$.

DeAngelo, Harry / Masulis, Ronald W. (1980): Optimal Capital Structure under Corporate and Personal Taxation, in: Journal of Financial Economics 8, p. 3-29.

Delcoure, Natalya (2007): The Determinants of Capital Structure in Transitional Economies, in: International Review of Economics and Finance 16, p. 400-415.

Faccio, Mara / Xu, Jin (2015): Taxes and Capital Structure, in: Journal of Financial and Quantitative Analysis 50, p. 277-300.

Feldstein, Martin / Summers, Lawrence (1979): Inflation and the Taxation of Capital Income in the Corporate Sector, in: National Tax Journal 32, p. 445-470.

Givoly, Dan / Hayn, Carla / Ofer, Aharon R. / Sarig, Oded (1992): Taxes and Capital Structure: Evidence from Firms' Response to the Tax Reform Act of 1986, in: Review of Financial Studies 5, p. 331-355.

Gordon, Roger H. / MacKie-Mason, Jeffrey K. (1990): Effects of the Tax Reform Act of 1986 on Corporate Financial Policy and Organizational Form, in: Slemrod, Joel: Do Taxes Matter? The Impact of the Tax Reform Act of 1986, London, p. 91-131. 
Graham, John R. (1999): Do Personal Taxes Affect Corporate Financing Decisions?, in: Journal of Public Economics 73, p. 147-185.

Harris, M. / Raviv, A. (1990): Capital Structure and the Informational Role of Debt, in: Journal of Finance 45, p. 321-349.

Holt, Charles / Shelton, John (1961): The Implications of the Capital Gains Tax for Investment Decisions, in: Journal of Finance 16, p. 559-580.

Huizinga, Harry / Laeven, Luc / Nicodeme, Gaetan (2008): Capital Structure and International Debt Shifting, in: Journal of Financial Economics 88, p. 80-118.

International Consortium of Investigative Journalists (2016): Luxembourg Leaks: Global Companies' Secrets Exposes, retrieved from: https://www.icij.org/project/luxembourgleaks, 2nd August 2016.

Iradian, Garbis (2007): Rapid Growth in Transition Economies: Growth-Accounting Approach, IMF Working Paper WP/07/164.

Jacob, Marcus / Jacob, Martin (2014): Taxation, Dividends, and Share Repurchases: Taking Evidence Global, in: Journal of Financial and Quantitative Analysis 48, p. 12411269.

Jacob, Martin / Michaely, Roni / Alstadsæter, Annette (2015): Taxation and Dividend Policy: The Muting Effect of Diverse Ownership Structure, Working Paper.

Jensen, Michael C. (1986): Agency Costs of Free Cash Flow, Corporate Finance and Takeovers, in: American Economic Review 76, p. 323-329.

Jensen, Michael C. / Meckling, William (1976): Theory of the Firm: Managerial Behaviour, Agency Costs and Ownership Structure, in: Journal of Financial Economics 3, p. 305-360.

Klapper, Leora F. / Sarria-Allende, Virginia / Sulla, Victor (2002): Small- and MediumSize Enterprise Financing in Eastern Europe, The World Bank Policy Research Working Paper No. 2933.

Krämer, Robert (2015): Taxation and Capital Structure Choice: The Role of Ownership, in: The Scandinavian Journal of Economics 117, p. 957-982.

Kraus, Alan / Litzenberger, Robert H. (1973): A State-preference Model of Optimal Financial Leverage, in: Journal of Finance 28, p. 911-922. 
Lace, Natalja / Bistrova, Julija / Kozlovskis, Konstantins (2013): Ownership Type Influence on Dividend Payments in CEE Countries, in: Business: Theory and Practice 14, p. 259-266.

MacKie-Mason, Jeffrey K. (1990): Do Taxes Affect Corporate Financing Decisions?, in: Journal of Finance 45, p. 1471-1493.

Miller, Merton H. (1977): Debt and Taxes, in: Journal of Finance 32, p. 261-274.

Modigliani, Franco / Miller, Merton H. (1958): The Cost of Capital, Corporate Finance and the Theory of Investment, in: American Economic Review 48, p. 261-297.

Modigliani, Franco / Miller, Merton H. (1963): Corporate Income Taxes and the Cost of Capital, in: American Economic Review 52, p. 433-442.

Myers, Stewart C. / Majluf, Nicholas S. (1984): Corporate Financing and Investment Decision when Firms Have Information that Investors Do Not Have, in: Journal of Financial Economics 13, p. 187-221.

Overesch, Michael / Voeller, Dennis (2010): The Impact of Personal and Corporate Taxation on Capital Structure Choices, in: FinanzArchiv 66, p. 263-294.

Pfaffermayr, Michael / Stöckl, Matthias / Winner, Hannes (2013): Capital Structure, Corporate Taxation and Firm Age, in: Fiscal Studies 34, p. 109-135.

Pindado, Julio / de la Torre, Chabela (2011): Capital Structure: New Evidence from the Ownership Structure, in: International Review of Finance 11, p. 213-226.

Rajan, Raghuram G. / Zingales, Luigi (1995): What Do We Know about Capital Structure? Some Evidence from International Data, in: Journal of Finance 50, p. 1113-1146.

Schulman, Craig T. / Thomas, Deborah W. / Sellers, Keith F. / Kennedy, Duane B. (1996): Effects of Tax Integration and Capital Gains Tax on Corporate Leverage, in: National Tax Journal 49, p. 31-54.

Scott, James H. (1977): A Theory of Optimal Capital Structure, in: Bell Journal of Economics 7, p. 33-54.

Shleifer, Andrei / Vishny, Robert W. (1986): Large Shareholders and Corporate Control, in: Journal of Political Economy 94, p. 461-488.

Sprinkel, Beryl / West, Kenneth (1962): Effects of Capital Gains Taxes on Investment Decisions, in: Journal of Business 35, p. 122-134. 
Trezevant, Robert (1992): Debt Financing and Tax Status: Tests of the Substitution Effect and the Tax Exhaustion Hypothesis Using Firms' Responses to the Economic Recovery Tax Act of 1981, in: Journal of Finance 47, p. 1557-1568.

Wald, John K. (1999): How Firm Characteristics Affect Capital Structure, in: Journal of Financial Research 12, p. 161-187.

Zwiebel, Jeffrey (1996): Dynamic Capital Structure under Managerial Entrenchment, in: American Economic Review 86, p. 1197-1215. 


\section{Appendix}

Table 1: Overview of tax rates, 2002-2012.

This table shows the range of tax rates on corporate profits, $\tau_{c}$, interest income, $\tau_{i}$, dividend payments received by individual domestic owners, $\tau_{d}$, and capital gains realized by individual domestic owners, $\tau_{g}$, for every sample country over the sample years 2002-2012.

\begin{tabular}{|l|c|c|c|c|}
\hline Country & $\tau_{c}$ & $\tau_{i}$ & $\tau_{d}$ & $\tau_{g}$ \\
\hline \hline Bulgaria & $10-20 \%$ & $0-20 \%$ & $5-15 \%$ & $10-38 \%$ \\
\hline Croatia & $20 \%$ & $0 \%$ & $0-15 \%$ & $0 \%$ \\
\hline Czech Republic & $19-31 \%$ & $15 \%$ & $15 \%$ & $15-32 \%$ \\
\hline Estonia & $0 \%$ & $21-26 \%$ & $21-26 \%$ & $21-26 \%$ \\
\hline Hungary & $10-18 \%$ & $0-20 \%$ & $16-25 \%$ & $10-40 \%$ \\
\hline Latvia & $15-25 \%$ & $10-25 \%$ & $0-10 \%$ & $15-23 \%$ \\
\hline Lithuania & $15-20 \%$ & $15 \%$ & $15-20 \%$ & $15 \%$ \\
\hline Poland & $19-28 \%$ & $19-20 \%$ & $15-19 \%$ & $19-40 \%$ \\
\hline Romania & $16-25 \%$ & $1-16 \%$ & $5-16 \%$ & $1-16 \%$ \\
\hline Russia & $20-35 \%$ & $13-35 \%$ & $6-30 \%$ & $0-13 \%$ \\
\hline Slovakia & $19-29 \%$ & $19-42 \%$ & $0-15 \%$ & $19-42 \%$ \\
\hline Slovenia & $20-25 \%$ & $20-50 \%$ & $20-30 \%$ & $20-50 \%$ \\
\hline Ukraine & $21-25 \%$ & $5-15 \%$ & $5-15 \%$ & $13-15 \%$ \\
\hline
\end{tabular}


Table 2: Net tax benefit of debt by country and year, 2002-2012.

This table shows the net tax benefit of debt calculated following the approach of Gordon / MacKie-Mason (1990). Tax rates are taken from Table 1 and results are based on the assumption that half of the firm's profits are distributed as dividends, thus $d=0.5$ and $\alpha=0.5$. Negative values are marked in bold and refer to country-years in which equity is preferred over debt due to the personal tax penalty.

\begin{tabular}{|r|r|r|r|r|r|r|}
\hline Country & $\mathbf{2 0 0 2}$ & $\mathbf{2 0 0 3}$ & $\mathbf{2 0 0 4}$ & $\mathbf{2 0 0 5}$ & $\mathbf{2 0 0 6}$ & $\mathbf{2 0 0 7}$ \\
\hline \hline Bulgaria & 0.0754 & 0.1478 & 0.1137 & 0.0308 & 0.0308 & $\mathbf{- 0 . 0 1 4 5}$ \\
\hline Croatia & 0.2600 & 0.2600 & 0.2600 & 0.2000 & 0.2000 & 0.2000 \\
\hline Czech Republic & 0.2670 & 0.2670 & 0.2416 & 0.2247 & 0.2078 & 0.2078 \\
\hline Estonia & $\mathbf{- 0 . 0 6 5 0}$ & $\mathbf{- 0 . 0 6 5 0}$ & $\mathbf{- 0 . 0 6 5 0}$ & $\mathbf{- 0 . 0 6 0 0}$ & $\mathbf{- 0 . 0 5 7 5}$ & $\mathbf{- 0 . 0 5 5 0}$ \\
\hline Hungary & 0.3440 & 0.3440 & 0.3238 & 0.3175 & 0.3175 & 0.3175 \\
\hline Latvia & 0.0187 & $\mathbf{- 0 . 0 0 9 4}$ & $\mathbf{- 0 . 0 4 6 9}$ & $\mathbf{- 0 . 0 4 6 9}$ & $\mathbf{- 0 . 0 4 6 9}$ & $\mathbf{- 0 . 0 4 6 9}$ \\
\hline Lithuania & 0.0956 & 0.0956 & 0.0956 & 0.0956 & 0.0956 & 0.0956 \\
\hline Poland & 0.2060 & 0.1978 & 0.1154 & 0.1154 & 0.1154 & 0.1154 \\
\hline Romania & 0.2606 & 0.2606 & 0.2606 & 0.1230 & 0.1008 & 0.1008 \\
\hline Russia & 0.1575 & 0.1575 & 0.1575 & 0.1689 & 0.1689 & 0.1689 \\
\hline Slovakia & $\mathbf{- 0 . 0 0 2 5}$ & $\mathbf{- 0 . 0 0 2 5}$ & 0.0385 & 0.0385 & 0.0385 & 0.0385 \\
\hline Slovenia & $\mathbf{- 0 . 0 4 3 8}$ & $\mathbf{- 0 . 0 4 3 8}$ & $\mathbf{- 0 . 0 4 3 8}$ & $\mathbf{- 0 . 0 4 3 8}$ & 0.2125 & 0.2125 \\
\hline Ukraine & 0.1931 & 0.1931 & 0.1931 & 0.1931 & 0.1931 & 0.1844 \\
\hline
\end{tabular}

\begin{tabular}{|r|r|r|r|r|r|r|}
\hline Country & $\mathbf{2 0 0 8}$ & $\mathbf{2 0 0 9}$ & $\mathbf{2 0 1 0}$ & $\mathbf{2 0 1 1}$ & $\mathbf{2 0 1 2}$ & avg. \\
\hline \hline Bulgaria & 0.1450 & 0.1450 & 0.1450 & 0.1450 & 0.1450 & 0.1008 \\
\hline Croatia & 0.2000 & 0.2000 & 0.2000 & 0.2000 & 0.2000 & 0.2164 \\
\hline Czech Republic & 0.1489 & 0.1400 & 0.1311 & 0.1311 & 0.1311 & 0.1907 \\
\hline Estonia & $\mathbf{- 0 . 0 5 2 5}$ & $\mathbf{- 0 . 0 5 2 5}$ & $\mathbf{- 0 . 0 5 2 5}$ & $\mathbf{- 0 . 0 5 2 5}$ & $\mathbf{- 0 . 0 5 2 5}$ & $\mathbf{- 0 . 0 5 7 3}$ \\
\hline Hungary & 0.1175 & 0.1175 & 0.0350 & 0.0345 & 0.0480 & 0.2106 \\
\hline Latvia & $\mathbf{- 0 . 0 4 6 9}$ & $\mathbf{- 0 . 0 3 1 1}$ & 0.1244 & 0.1244 & 0.1244 & 0.0106 \\
\hline Lithuania & 0.0956 & 0.1600 & 0.1169 & 0.1169 & 0.1169 & 0.1073 \\
\hline Poland & 0.1154 & 0.1154 & 0.1154 & 0.1154 & 0.1154 & 0.1311 \\
\hline Romania & 0.1008 & 0.1008 & 0.1008 & 0.1008 & 0.1008 & 0.1464 \\
\hline Russia & 0.1689 & 0.1320 & 0.1320 & 0.1060 & 0.1060 & 0.1476 \\
\hline Slovakia & 0.0385 & 0.0385 & 0.0385 & 0.0385 & 0.0385 & 0.0310 \\
\hline Slovenia & 0.1370 & 0.1285 & 0.1200 & 0.1200 & 0.1200 & 0.0796 \\
\hline Ukraine & 0.1844 & 0.1844 & 0.1844 & 0.2469 & 0.2094 & 0.1975 \\
\hline
\end{tabular}


Table 3: Sample Generation Process.

This table shows the sample generation process. We start with all firms from 13 CEE-countries with financial reports available for at least one year (2002-2012) in the Amadeus database. After dropping firms with missing data on payout ratio and ownership, our main sample consists of 44,924 firm-year observations and 10,983 firms.

\begin{tabular}{|l|r|r|}
\hline Description & firm-year obs. & firms \\
\hline \hline financial reports available & 94,812 & 16,510 \\
\hline - missing data on payout ratio & $-13,755$ & $-3,728$ \\
\hline - missing or incomplete ownership data & $-36,133$ & $-1,799$ \\
\hline \hline $\begin{array}{l}\text { Final Sample (ownership information and } \\
\text { full accounting information) }\end{array}$ & 44,924 & 10,983 \\
\hline
\end{tabular}

Table 4: Average firm-specific debt ratio, payout ratio and net tax benefit of debt by year, 2002-2012.

This table shows the average firm-specific debt ratio (sum of current and non-current liabilities divided by total assets) as well as the average firm-specific payout ratio calculated as shown in equation (3). In addition, we present the average firm-specific net tax benefit of debt, calculated according to Gordon/MacKie-Mason (1990). For the calculation we use data from our sample consisting of 44,924 firm-year observations and 10,983 firms.

\begin{tabular}{|l|r|r|r|r|r|r|r|}
\hline Country & \multicolumn{2}{|c|}{ Debt Ratio } & \multicolumn{2}{|c|}{ Payout Ratio } & \multicolumn{2}{|c|}{ NTBD } & \\
\hline & Mean & Std.Dev. & Mean & Std.Dev. & Mean & Std.Dev. & obs. \\
\hline 2002 & 0.6173 & 0.2487 & 0.1887 & 0.3328 & 0.2169 & 0.0942 & 660 \\
2003 & 0.6217 & 0.2521 & 0.3547 & 0.4181 & 0.2263 & 0.0848 & 815 \\
2004 & 0.6293 & 0.2576 & 0.4204 & 0.4167 & 0.1944 & 0.1057 & 1,847 \\
2005 & 0.6277 & 0.2575 & 0.2164 & 0.3511 & 0.1239 & 0.0835 & 2,362 \\
2006 & 0.6346 & 0.2673 & 0.1921 & 0.3415 & 0.1086 & 0.0741 & 2,694 \\
2007 & 0.7305 & 0.2892 & 0.2457 & 0.3542 & 0.1322 & 0.0657 & 5,174 \\
2008 & 0.7392 & 0.3003 & 0.2668 & 0.3634 & 0.1378 & 0.0634 & 4,815 \\
2009 & 0.6977 & 0.3311 & 0.4306 & 0.4271 & 0.1288 & 0.0456 & 7,929 \\
2010 & 0.6001 & 0.2962 & 0.3811 & 0.4214 & 0.1231 & 0.0487 & 6,274 \\
2011 & 0.5872 & 0.2884 & 0.2358 & 0.3646 & 0.1035 & 0.0597 & 5,919 \\
2012 & 0.6975 & 0.2806 & 0.3966 & 0.4278 & 0.1171 & 0.0639 & 6,399 \\
\hline total & 0.6648 & 0.2790 & 0.3233 & 0.4029 & 0.1287 & 0.0687 & 44,924 \\
\hline
\end{tabular}


Table 5: Average firm-specific debt ratio, payout ratio and net tax benefit of debt by country, 2002-2012.

This table shows the average firm-specific debt ratio (sum of current and non-current liabilities divided by total assets) as well as the average firm-specific payout ratio calculated as shown in equation (3). In addition, we present the average firm-specific net tax benefit of debt, calculated according to Gordon/MacKie-Mason (1990). All values presented are country averages. For the calculation we use data from our sample consisting of 44,924 firm-year observations and 10,983 firms.

\begin{tabular}{|l|r|r|r|r|r|r|r|}
\hline & \multicolumn{2}{|c|}{ Debt Ratio } & \multicolumn{2}{c|}{ Payout Ratio } & \multicolumn{2}{c|}{ NTBD } & \\
\hline Year & Mean & Std.Dev. & Mean & Std.Dev. & Mean & Std.Dev. & obs. \\
\hline Bulgaria & 0.6419 & 0.3996 & 0.2319 & 0.3628 & 0.1088 & 0.0541 & 2,322 \\
Croatia & 0.6269 & 0.5593 & 0.3681 & 0.4246 & 0.2131 & 0.0328 & 4,104 \\
Czech Republic & 0.4654 & 0.2689 & 0.2659 & 0.3853 & 0.1422 & 0.0543 & 1,585 \\
Estonia & 0.4331 & 0.2941 & 0.1885 & 0.3197 & -0.0886 & 0.0352 & 1,266 \\
Hungary & 0.5682 & 0.2157 & 0.2774 & 0.3615 & 0.2745 & 0.1081 & 733 \\
Latvia & 0.7001 & 0.3676 & 0.3414 & 0.3874 & 0.0192 & 0.0754 & 618 \\
Lithuania & 0.5577 & 0.2229 & 0.2416 & 0.3572 & 0.0887 & 0.0351 & 1,323 \\
Poland & 0.5518 & 0.3938 & 0.3095 & 0.4078 & 0.1051 & 0.0376 & 5,151 \\
Romania & 0.6204 & 0.3042 & 0.3411 & 0.4111 & 0.1168 & 0.0621 & 4,716 \\
Russia & 0.7475 & 0.5261 & 0.3531 & 0.4059 & 0.1302 & 0.0323 & 19,862 \\
Slovakia & 0.5202 & 0.2447 & 0.4131 & 0.4392 & 0.0451 & 0.0338 & 232 \\
Slovenia & 0.6637 & 0.2556 & 0.1806 & 0.3381 & 0.0969 & 0.0275 & 618 \\
Ukraine & 0.7445 & 0.4065 & 0.2754 & 0.3974 & 0.1937 & 0.0327 & 2,394 \\
\hline total & 0.6648 & 0.2790 & 0.3233 & 0.4029 & 0.1287 & 0.0687 & 44,924 \\
\hline
\end{tabular}

Table 6: Average combined holding of owner types by country, 2002-2012.

This table shows the average combined holding of six different owner types provided by Amadeus (domestic individual, domestic corporate, foreign, domestic financial, funds and state) in \% for all 13 sample countries over the years 2002-2012.

\begin{tabular}{|l|r|r|r|r|r|r|r|}
\hline Country & individual & corporate & foreign & financial & funds & state & obs \\
\hline Bulgaria & 72.53 & 13.86 & 10.97 & 1.89 & 0.10 & 0.38 & 2,322 \\
Croatia & 68.28 & 14.04 & 11.46 & 1.19 & 2.45 & 2.20 & 4,104 \\
Czech Republic & 77.70 & 11.09 & 8.91 & 1.01 & 0.35 & 0.57 & 1,585 \\
Estonia & 72.24 & 9.72 & 12.37 & 5.16 & 0.22 & 0.00 & 1,266 \\
Hungary & 67.48 & 9.28 & 22.21 & 0.03 & 0.01 & 0.04 & 733 \\
Latvia & 84.43 & 5.04 & 9.31 & 0.81 & 0.10 & 0.00 & 618 \\
Lithuania & 76.64 & 14.72 & 4.76 & 2.64 & 0.45 & 0.01 & 1,323 \\
Poland & 81.93 & 6.68 & 8.74 & 0.41 & 0.31 & 0.97 & 5,151 \\
Romania & 63.56 & 12.52 & 21.74 & 1.04 & 0.54 & 0.21 & 4,716 \\
Russia & 77.24 & 13.15 & 4.41 & 4.25 & 0.28 & 0.47 & 19,862 \\
Slovakia & 82.49 & 1.47 & 15.04 & 0.03 & 0.51 & 0.00 & 232 \\
Slovenia & 71.54 & 18.39 & 7.28 & 2.32 & 0.23 & 0.00 & 618 \\
Ukraine & 72.78 & 12.88 & 11.23 & 1.68 & 0.56 & 0.79 & 2,394 \\
\hline total & 74.69 & 12.28 & 8.83 & 2.71 & 0.51 & 0.62 & 44,924 \\
\hline
\end{tabular}




\section{Table 7: Percentage of sample firms with an individual domestic marginal owner, 2002-2012.}

This table shows the percentage of sample firms for which the marginal owner is an individual domestic owner for all 13 sample countries over the years 2002-2012. We consider four different definitions of the marginal owner. MOwn 1 refers to firms where the largest individual domestic owner has more than $50 \%$ of the shares of the firm. Subsequently, MOwn12 and MOwn123 refer to firms where the 2 (3) largest individual domestic owners together have more than $50 \%$ of the shares of the firm. MOwnAll shows the percentage of sample firms where the combined holding of all individual domestic owners is above $50 \%$.

\begin{tabular}{|l|r|r|r|r|}
\hline Country & MOwn1 & MOwn12 & MOwn123 & MOwnAll \\
\hline Bulgaria & 46.18 & 72.39 & 74.62 & 75.65 \\
Croatia & 60.43 & 69.78 & 71.87 & 73.14 \\
Czech Republic & 53.88 & 68.70 & 70.57 & 71.79 \\
Estonia & 50.08 & 72.84 & 76.88 & 76.97 \\
Hungary & 40.56 & 72.01 & 73.67 & 74.33 \\
Latvia & 48.12 & 79.78 & 84.39 & 86.52 \\
Lithuania & 60.81 & 72.67 & 77.24 & 78.11 \\
Poland & 42.33 & 74.87 & 80.34 & 81.21 \\
Romania & 49.98 & 71.03 & 72.33 & 72.92 \\
Russia & 71.61 & 77.69 & 79.07 & 79.65 \\
Slovakia & 31.19 & 33.48 & 34.86 & 36.69 \\
Slovenia & 43.37 & 57.66 & 61.14 & 63.58 \\
Ukraine & 38.63 & 66.65 & 72.92 & 75.12 \\
\hline total & 58.90 & 73.99 & 76.48 & 77.36 \\
\hline
\end{tabular}


Table 8: Summary Statistics, 2002-2012.

This table shows summary statistics for the two tax control variables, NTBD and ThinCap, as well as the nontax firm-level and country-level control variables used in the regression model. $N T B D$ is calculated according to equation (1) and ThinCap is a dummy variable taking the value 1 if a thin-capitalization rule exists in a country in the considered year. Firm-level control variables include $N O L$, a dummy variable taking the value 1 if there is a negative EBIT in the year before, Profit (EBIT deflated by total assets), Size (natural log of total assets), Tangibles (tangible assets deflated by total assets), Age (firm age in years) and ForSub (number of foreign subsidiaries). Country-level control variables are Law (rule of law estimate of the Worldbank), EU, a dummy variable taking the value 1 if the country is a EU-member in the current year and Market (stock market capitalization deflated by GDP). Statistics are calculated based on 44,924 firm-year observations from 10,983 firms.

\begin{tabular}{|l|c|c|c|c|c|}
\hline Variable & Mean & Std. Dev. & Min & Max & N \\
\hline \hline NTBD & 0.1287 & 0.0687 & -0.13 & 0.37 & 44,924 \\
\hline ThinCap & 0.9138 & 0.2806 & 0 & 1 & 44,924 \\
\hline NOL & 0.1781 & 0.3826 & 0 & 1 & 44,924 \\
\hline Profit & 0.0481 & 0.01346 & -3.8559 & 9.5138 & 44,924 \\
\hline Size & $56,470,440$ & $739,398,100$ & 1,000 & $62,185,410,000$ & 44,924 \\
\hline Tangibles & $16,764,160$ & $317,453,000$ & 0 & $40,055,510,000$ & 44,924 \\
\hline Age & 31.37 & 36.51 & 1 & 301 & 44,924 \\
\hline ForSub & 0.0724 & 0.7717 & 0 & 42 & 44,924 \\
\hline Law & -0.2295 & 0.6762 & -0.9945 & 1.1653 & 44,924 \\
\hline EU & 0.3360 & 0.4723 & 0 & 1 & 44,924 \\
\hline Market & 0.4197 & 0.2891 & 0.0380 & 1.1564 & 44,924 \\
\hline
\end{tabular}




\section{Table 9: Investor Taxation and Capital Structure Choice, 2002-2012.}

This table shows regression results for equations (4) and (5), investigating the influence of investor level taxes on capital structure choice. $N T B D$ is calculated according to equation (6), assuming that all profits are distributed as dividends and therefore ignoring firm-specific payout policy. ThinCap is a dummy variable taking the value 1 if a thin-capitalization rule exists in a country in the considered year. Firm-level control variables include $N O L$, a dummy variable taking the value 1 if there is a negative EBIT in the year before, Profit (EBIT deflated by total assets), Size (natural log of total assets), Tangibles (tangible assets deflated by total assets), Age (firm age in years) and For Sub (number of foreign subsidiaries). Country-level control variables are Law (rule of law estimate of the Worldbank), EU, a dummy variable taking the value 1 if the country is a EU-member in the current year and Market (stock market capitalization deflated by GDP). In all regressions, firm- and year-fixed effects are included. Robust standard errors, clustered at country-level, are presented in parentheses. The superscripts $* * *, * *$, and $*$ indicate the statistical significance at the $1 \%, 5 \%$, and $10 \%$ levels, respectively.

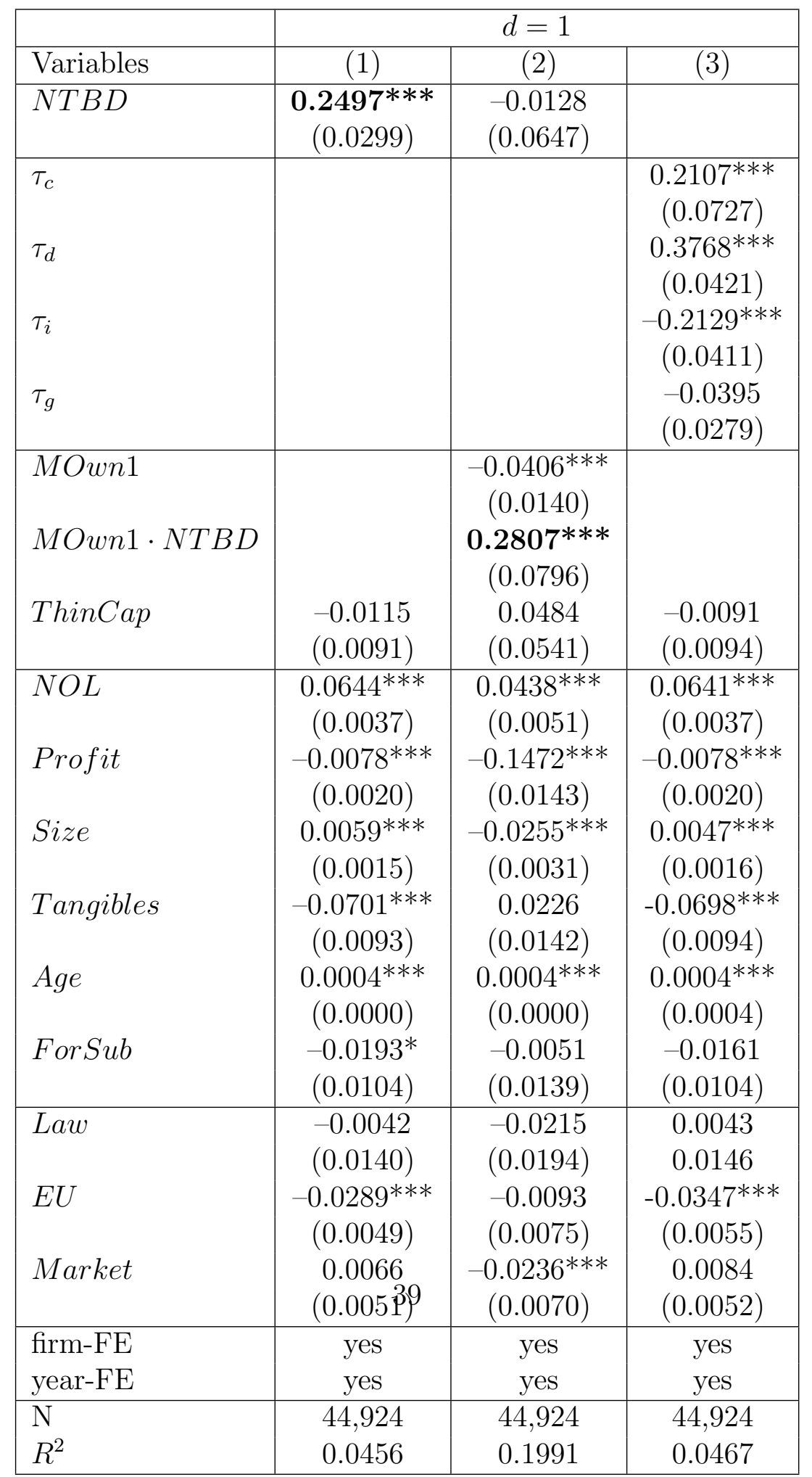




\section{Table 10: Investor Taxation, Firm Heterogeneity and Capital Structure Choice, 2002-2012.}

This table shows regression results for equations (4) and (5), investigating the influence of investor level taxes and firm heterogeneity on capital structure choice. $N T B D$ is calculated according to equation (1) including firm-specific payout policy. ThinCap is a dummy variable taking the value 1 if a thin-capitalization rule exists in a country in the considered year. Firm-level control variables include $N O L$, a dummy variable taking the value 1 if there is a negative EBIT in the year before, Profit (EBIT deflated by total assets), Size (natural log of total assets), Tangibles (tangible assets deflated by total assets), Age (firm age in years) and ForSub (number of foreign subsidiaries). Country-level control variables are Law (rule of law estimate of the Worldbank), EU, a dummy variable taking the value 1 if the country is a EU-member in the current year and Market (stock market capitalization deflated by GDP). In all regressions, firm- and year-fixed effects are included. Robust standard errors, clustered at country-level, are presented in parentheses. The superscripts ***, **, and * indicate the statistical significance at the $1 \%, 5 \%$, and $10 \%$ levels, respectively.

\begin{tabular}{|c|c|c|}
\hline & \multicolumn{2}{|c|}{ firm-specific $d$} \\
\hline Variables & (4) & $(5)$ \\
\hline$N T B D$ & $0.0942 * * *$ & $-0.1122^{* *}$ \\
\hline 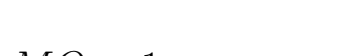 & $(0.0266)$ & $(0.0272)$ \\
\hline MOwn 1 & & $\begin{array}{c}-0.0261^{* *} \\
(0.0108)\end{array}$ \\
\hline$M O w n 1 \cdot N T B D$ & & $\begin{array}{c}\mathbf{0 . 2 3 8 9} * * * \\
(0.0685)\end{array}$ \\
\hline ThinCap & -0.0035 & 0.0496 \\
\hline & $(0.0090)$ & $(0.0542)$ \\
\hline NOL & $\begin{array}{c}0.0656^{* * * *} \\
(0.0037)\end{array}$ & $\begin{array}{c}0.0441^{* * *} \\
(0.0051)\end{array}$ \\
\hline Profit & $\begin{array}{c}-0.0077^{* * *} \\
(0.0020)\end{array}$ & $\begin{array}{c}-0.1471^{* * *} \\
(0.0143)\end{array}$ \\
\hline Size & $\begin{array}{c}0.0058^{* * * *} \\
(0.0015)\end{array}$ & $\begin{array}{c}-0.0265^{* * *} \\
(0.0031)\end{array}$ \\
\hline Tangibles & $\begin{array}{c}-0.0736^{* * *} \\
(0.0093)\end{array}$ & $\begin{array}{c}0.0216 \\
(0.0142)\end{array}$ \\
\hline Age & $\begin{array}{c}0.0003^{* * * *} \\
(0.0000)\end{array}$ & $\begin{array}{c}0.0004^{* * * *} \\
(0.0000)\end{array}$ \\
\hline ForSub & $\begin{array}{c}-0.0188^{*} \\
(0.0104)\end{array}$ & $\begin{array}{l}-0.0050 \\
(0.0139)\end{array}$ \\
\hline Law & $\begin{array}{l}-0.0167 \\
(0.0137)\end{array}$ & $\begin{array}{l}-0.0343^{*} \\
(0.0190)\end{array}$ \\
\hline$E U$ & $\begin{array}{c}-0.0298^{* *} \\
(0.0050)\end{array}$ & $\begin{array}{l}-0.0101 \\
(0.0076)\end{array}$ \\
\hline Market & $\begin{array}{c}0.0029 \\
(0.0051)\end{array}$ & $\begin{array}{c}-0.0278^{* * *} \\
(0.0069)\end{array}$ \\
\hline firm-FE & yes & yes \\
\hline year-FE & yes & yes \\
\hline $\mathrm{N}$ & 44,924 & 44,924 \\
\hline$R^{2}$ & 0.0465 & 0.1975 \\
\hline
\end{tabular}




\section{Table 11: Different Definitions of the Marginal Owner and Capital Structure Choice, 2002-2012.}

This table shows regression results for different definitions of the marginal owner. In columns (1) and (4) we classify firms to have an individual domestic marginal owner if the combined share of the two largest individual domestic owners is above 50\%; in columns (2) and (5) we look at the combined holding of the three largest individual domestic owners. In columns (3) and (6) firms are categorized as having an individual domestic marginal owner if the combined holding of all individual domestic owners is above $50 \%$. Columns (1) to (3) do not include firm-specific payout policy, (4) to (6) integrate firm-specific payout policy into the calculation of the net tax benefit of debt. The definition of all variables is the same as in Tables 9 and 10 . In all regressions, firm- and year-fixed effects are included. Robust standard errors, clustered at country-level, are presented in parentheses. The superscripts ${ }^{* * *},{ }^{* *}$, and * indicate the statistical significance at the 1\%, $5 \%$, and $10 \%$ levels, respectively.

\begin{tabular}{|c|c|c|c|c|c|c|}
\hline & \multicolumn{3}{|c|}{$d=1$} & \multicolumn{3}{|c|}{ firm-specific $d$} \\
\hline & (1) & $(2)$ & $(3)$ & $(4)$ & $(5)$ & $(6)$ \\
\hline Variables & MOwn 12 & MOwn123 & MOwnAll & MOwn12 & MOwn 123 & MOwnAll \\
\hline \multirow[t]{2}{*}{$N T B D$} & -0.0065 & 0.0150 & 0.0145 & $-0.1457^{* *}$ & $-0.1323^{*}$ & $-0.1372^{*}$ \\
\hline & $(0.0844)$ & $(0.0893)$ & $(0.0900)$ & $(0.0708)$ & $(0.0754)$ & $(0.0760)$ \\
\hline \multirow[t]{2}{*}{ MOwn } & -0.0138 & -0.0067 & -0.0091 & -0.0107 & -0.0060 & -0.0091 \\
\hline & $(0.0161)$ & $(0.0168)$ & $(0.0168)$ & $(0.0123)$ & $(0.0129)$ & $(0.0129)$ \\
\hline MOwn & $0.1920 * *$ & $0.1579 *$ & $0.1575 *$ & $0.2152^{* * *}$ & $0.1905^{* *}$ & $0.1958 * *$ \\
\hline$\cdot N T B D$ & $(0.0910)$ & $(0.0947)$ & $(0.0952)$ & $(0.0775)$ & $(0.0811)$ & $(0.0815)$ \\
\hline \multirow[t]{2}{*}{ ThinCap } & 0.0466 & 0.0466 & 0.0467 & 0.0489 & 0.0485 & 0.0486 \\
\hline & $(0.0541)$ & $(0.0541)$ & $(0.0542)$ & $(0.0542)$ & $(0.0542)$ & $(0.0542)$ \\
\hline \multirow[t]{2}{*}{$N O L$} & $0.0439^{* * *}$ & $0.0438^{* * *}$ & $0.0438^{* * *}$ & $0.0439 * * *$ & $0.0439^{* * *}$ & $0.0439 * * *$ \\
\hline & $(0.0051)$ & $(0.0051)$ & $(0.0051)$ & $(0.0051)$ & $(0.0051)$ & $(0.0051)$ \\
\hline \multirow[t]{2}{*}{ Profit } & $-0.1471^{* * *}$ & $-0.1471^{* * *}$ & $-0.1471^{* * *}$ & $-0.1471^{* * *}$ & $-0.1471^{* * *}$ & $-0.1471^{* * *}$ \\
\hline & $(0.0143)$ & $(0.0143)$ & $(0.0143)$ & $(0.0144)$ & $(0.0146)$ & $(0.0144)$ \\
\hline \multirow[t]{2}{*}{ Size } & $-0.0255^{* * *}$ & $-0.0255^{* * *}$ & $-0.0255^{* * *}$ & $-0.0263^{* * *}$ & $-0.0264^{* * *}$ & $-0.0263^{* * *}$ \\
\hline & $(0.0031)$ & $(0.0031)$ & $(0.0031)$ & $(0.0031)$ & $(0.0031)$ & $(0.0031)$ \\
\hline \multirow[t]{2}{*}{ Tangibles } & 0.0227 & 0.0228 & 0.0229 & 0.0221 & 0.0223 & 0.0223 \\
\hline & $(0.0142)$ & $(0.0142)$ & $(0.0142)$ & $(0.0142)$ & $(0.0142)$ & $(0.0142)$ \\
\hline \multirow[t]{2}{*}{ Age } & $0.0005^{* * *}$ & $0.0005^{* * *}$ & $0.0005^{* * *}$ & $0.0005^{* * *}$ & $0.0005^{* * *}$ & $0.0005^{* * *}$ \\
\hline & $(0.0001)$ & $(0.0001)$ & $(0.0001)$ & $(0.0001)$ & $(0.0001)$ & $(0.0001)$ \\
\hline \multirow[t]{2}{*}{ ForSub } & -0.0044 & -0.0048 & -0.0051 & -0.0042 & -0.0047 & $-0.0050^{* * *}$ \\
\hline & $(0.0139)$ & $(0.0139)$ & $(0.0139)$ & $(0.0139)$ & $(0.0139)$ & $(0.0139)$ \\
\hline \multirow[t]{2}{*}{ Law } & -0.0250 & -0.0267 & -0.0226 & $-0.0370^{*}$ & $-0.0382^{* *}$ & -0.0388 \\
\hline & $(0.0193)$ & $(0.0192)$ & $(0.0193)$ & $(0.0189)$ & $(0.0189)$ & $(0.0189)$ \\
\hline \multirow[t]{2}{*}{$E U$} & -0.0086 & -0.0085 & -0.0084 & -0.0087 & -0.0086 & -0.0086 \\
\hline & $(0.0075)$ & $(0.0076)$ & $(0.0076)$ & $(0.0076)$ & $(0.0076)$ & $(0.0076)$ \\
\hline \multirow[t]{2}{*}{ Market } & $-0.0240^{* * *}$ & $-0.0239 * * *$ & $-0.0326^{* * *}$ & $-0.0270 * * *$ & $-0.0271^{* * *}$ & $-0.0270^{* * *}$ \\
\hline & $(0.0070)$ & $(0.0070)$ & $(0.0070)$ & $(0.0069)$ & $(0.0069)$ & $(0.0069)$ \\
\hline \multirow{2}{*}{$\begin{array}{l}\text { firm-FE } \\
\text { year-FE }\end{array}$} & yes & yes & yes & yes & yes & yes \\
\hline & yes & yes & yes & yes & yes & yes \\
\hline $\mathrm{N}$ & 44,924 & 44,924 & 44,924 & 44,924 & 44,924 & 44,924 \\
\hline$R^{2}$ & 0.1987 & 0.1989 & 0.1986 & 0.1971 & 0.1975 & 0.1983 \\
\hline
\end{tabular}




\section{Table 12: Incremental Definition of the Marginal Owner and Capital Structure Choice, 2002-2012.}

This table shows regression results for an incremental definition of the marginal owner. MOwn 1 takes the value 1 for firms for which the largest individual domestic owner has more than $50 \%$ of the shares. MOwn 2 takes the value 1 if the share of the two largest individual domestic owner is above $50 \%$, but only if $M O w n 1=0$. MOwn 3 takes the value 1 if the share of the three largest individual domestic owner is above $50 \%$, but only if MOwn $1=0$ and MOwn $2=0$ and MOwnAllIncre takes the value 1 for all firm for which only the combined share of more than the three largest individual domestic owner is above $50 \%$. Column (1) does not include firm-specific payout policy, column (2) integrates firm-specific payout policy into the calculation of the net tax benefit of debt. All variables from Table 10 are included in the regressions, but not reported in this table. In all regressions, firm- and year-fixed effects are included. Robust standard errors, clustered at country-level, are presented in parentheses. The superscripts ***, **, and * indicate the statistical significance at the $1 \%, 5 \%$, and $10 \%$ levels, respectively.

\begin{tabular}{|l|c|c|}
\hline & $(1)$ & $(2)$ \\
\hline$d$ & $d=1$ & firm-specific $d$ \\
\hline NTBD & 0.0279 & $-0.1279^{*}$ \\
& $(0.0886)$ & $(0.0752)$ \\
\hline MOwn 1 & -0.0254 & -0.0197 \\
MOwn2 & $(0.0177)$ & $(0.0136)$ \\
& 0.0291 & 0.0144 \\
MOwn3 & $(0.0210)$ & $(0.0162)$ \\
& 0.0488 & 0.0191 \\
MOwnAllIncre & $(0.0382)$ & $(0.0275)$ \\
& -0.0819 & -0.1001 \\
MOwn $1 \cdot$ NTBD & $(0.0987)$ & $(0.0768)$ \\
MOwn2 $\cdot$ NTBD & $0.2428^{* *}$ & $0.2572^{* * *}$ \\
& $(0.0996)$ & $(0.0855)$ \\
MOwn3 NTBD & -0.0421 & 0.0602 \\
& $(0.1182)$ & $(0.1026)$ \\
MOwnAllIncre $\cdot$ NTBD & -0.3211 & -0.1768 \\
& $(0.2221)$ & $(0.1824)$ \\
\hline N & 0.1816 & 0.3395 \\
\hline R & $(0.5437)$ & $(0.4831)$ \\
\hline
\end{tabular}




\section{Table 13: Alternative Measures of the Effective Capital Gains Tax Rate, 2002-2012.}

This table shows regression results for different measures of the capital gains discounting factor, $\alpha$, using firmspecific dividend payout ratios. All variables from Table 10 are included in the regressions, but only the two main coefficients of interest, $N T B D$ and $M O w n \cdot N T B D$, are reported in this table. Results are given for two definitions of the marginal owner: MOwn1 refers to firms for which the largest individual domestic owner has more than $50 \%$ of the shares and MOwnAll to firms for which all individual domestic owners together have more than $50 \%$ of the shares. In all regressions, firm- and year-fixed effects are included. Robust standard errors, clustered at country-level, are presented in parentheses. The superscripts ***, **, and * indicate the statistical significance at the $1 \%, 5 \%$, and $10 \%$ levels, respectively.

\begin{tabular}{|r|r|r|r|r|}
\hline & \multicolumn{2}{|c|}{$(1)$} & \multicolumn{2}{c|}{$(2)$} \\
\hline$\alpha$ & \multicolumn{2}{|c|}{0.25} & \multicolumn{2}{c|}{1} \\
\hline Variables & MOwn1 & MOwnAll & MOwn1 & MOwnAll \\
\hline NTBD & -0.0843 & -0.1148 & $-0.0991^{* *}$ & $-0.1178^{* *}$ \\
& $(0.0554)$ & $(0.0765)$ & $(0.0475)$ & $(0.0668)$ \\
MOwn. & $0.2081^{* *}$ & $0.1889^{* *}$ & $0.1982^{* * *}$ & $0.1568^{* *}$ \\
NTBD & $(0.0682)$ & $(0.0821)$ & $(0.0609)$ & $(0.0722)$ \\
\hline $\mathrm{N}$ & 44,924 & 44,924 & 44,924 & 44,924 \\
\hline$R^{2}$ & 0.1959 & 0.1957 & 0.1971 & 0.1973 \\
\hline
\end{tabular}




\section{Table 14: Alternative Measures of Firm-Specific Payout Policy, 2002-2012.}

This table shows regression results for different measures of the firm-specific dividend payout ratio, $d$. All variables from Table 10 are included in the regression, but only the two main coefficients of interest, $N T B D$ and MOwn $\cdot N T B D$, are reported in this table. Results are given for two definitions of the marginal owner: MOwn 1 refers to firms for which the largest individual domestic owner has more than $50 \%$ of the shares and MOwnAll to firms for which all individual domestic owners together have more than $50 \%$ of the shares. In all regressions, firm- and year-fixed effects are included. Robust standard errors, clustered at country-level, are presented in parentheses. The superscripts $* * *, * *$, and * indicate the statistical significance at the $1 \%, 5 \%$, and $10 \%$ levels, respectively.

\begin{tabular}{|c|c|c|c|c|c|c|}
\hline & \multicolumn{2}{|c|}{ (1) } & \multicolumn{2}{|c|}{$(2)$} & \multicolumn{2}{|c|}{ (3) } \\
\hline$d$ & \multicolumn{2}{|c|}{ 3y_avg_firm } & \multicolumn{2}{|c|}{ avg_countryyear } & \multicolumn{2}{|c|}{0.5} \\
\hline Variables & MOwn1 & MOwnAll & MOwn1 & MOwnAll & MOwn1 & MOwnAll \\
\hline$N T B D$ & $\begin{array}{r}-0.1530 * * \\
(0.0678)\end{array}$ & $\begin{array}{c}-0.1485 \\
(0.0924)\end{array}$ & $\begin{array}{l}-0.1000 \\
(0.0661)\end{array}$ & $\begin{array}{c}-0.1484 \\
(0.0932)\end{array}$ & $\begin{array}{r}-0.0816 \\
(0.0678)\end{array}$ & $\begin{array}{r}-0.1047 \\
(0.0945)\end{array}$ \\
\hline MOwn. & $0.3725^{* * *}$ & $0.2557^{* * *}$ & $0.3080^{* * *}$ & $0.2663^{*}$ & $0.3201^{* * *}$ & $0.2457^{* *}$ \\
\hline$N T B D$ & $(0.0825)$ & $(0.0975)$ & $(0.0809)$ & $(0.0974)$ & $(0.0821)$ & $(0.0985)$ \\
\hline combined effect & 0.2195 & 0.1072 & 0.2080 & 0.1179 & 0.2385 & 0.1410 \\
\hline $\mathrm{N}$ & 44,924 & 44,924 & 44,924 & 44,924 & 44,924 & 44,924 \\
\hline \multirow[t]{2}{*}{$R^{2}$} & 0.0428 & 0.0351 & 0.0311 & 0.0421 & 0.1005 & 0.0978 \\
\hline & \multicolumn{2}{|c|}{$(4)$} & \multicolumn{2}{|c|}{ (5) } & & \\
\hline$d$ & \multicolumn{2}{|c|}{ only OtherSF } & \multicolumn{2}{|c|}{ avg firm } & & \\
\hline Variables & MOwn 1 & MOwnAll & MOwn1 & MOwnAll & & \\
\hline$N T B D$ & $\begin{array}{r}-0.1526^{* * *} \\
(0.0574)\end{array}$ & $\begin{array}{r}-0.1571^{* *} \\
(0.0795)\end{array}$ & $\begin{array}{r}-0.1474^{* *} \\
(0.0624)\end{array}$ & $\begin{array}{r}-0.1553^{*} \\
(0.0867)\end{array}$ & & \\
\hline MOwn. & $0.3381^{* * *}$ & $0.2401^{* *}$ & $0.2838 * * *$ & $0.1828^{* *}$ & & \\
\hline$N T B D$ & $(0.0718)$ & $(0.0853)$ & $(0.0746)$ & $(0.0902)$ & & \\
\hline combined effect & 0.1855 & 0.0830 & 0.1364 & 0.0275 & & \\
\hline $\mathrm{N}$ & 44,924 & 44,924 & 44,924 & 44,924 & & \\
\hline$R^{2}$ & 0.0145 & 0.0149 & 0.1028 & 0.1009 & & \\
\hline
\end{tabular}




\section{Table 15: Sample Excluding Russian Firms, 2002-2012.}

This table shows regression results if we exclude all firms from Russia using firm-specific payout ratios. All variables from Table 10 are included in the regressions, but only the two main coefficients of interest, $N T B D$ and MOwn $\cdot N T B D$, are reported in this table. Results are given for two definitions of the marginal owner: MOwn1 refers to firms for which the largest individual domestic owner has more than $50 \%$ of the shares and MOwnAll to firms for which all individual domestic owners together have more than $50 \%$ of the shares. In all regressions, firm- and year-fixed effects are included. Robust standard errors, clustered at country-level, are presented in parentheses. The superscripts $* * *, * *$, and $*$ indicate the statistical significance at the $1 \%, 5 \%$, and $10 \%$ levels, respectively.

\begin{tabular}{|r|r|r|}
\hline excluded & \multicolumn{2}{|c|}{ Russia } \\
\hline Variables & MOwn 1 & MOwnAll \\
\hline NTBD & $-0.1243^{*}$ & $-0.1521^{*}$ \\
& $(0.0644)$ & $(0.0909)$ \\
MOwn. & $0.1632^{* *}$ & 0.1384 \\
NTBD & $(0.0850)$ & $(0.0960)$ \\
\hline combined effect & 0.0389 & -0.0137 \\
\hline $\mathrm{N}$ & 25,062 & 25,062 \\
\hline$R^{2}$ & 0.0263 & 0.0261 \\
\hline
\end{tabular}

\section{Table 16: Alternative Definition of Firm-Specific Payout Policy, 2002-2012.}

This table shows regression results if we exclude all firm-years for which the increase in shareholder funds from $t-1$ to $t$ is larger than the observed profit in $t$. All variables from Table 10 are included in the regressions, but only the two main coefficients of interest, NTBD and MOwn $\cdot N T B D$, are reported in this table. Results are given for two definitions of the marginal owner: MOwn1 refers to firms for which the largest individual domestic owner has more than $50 \%$ of the shares and MOwnAll to firms for which all individual domestic owners together have more than $50 \%$ of the shares. In all regressions, firm- and year-fixed effects are included. Robust standard errors, clustered at country-level, are presented in parentheses. The superscripts ***, **, and * indicate the statistical significance at the 1\%,5\%, and $10 \%$ levels, respectively.

\begin{tabular}{|r|r|r|}
\hline excluded & \multicolumn{2}{|c|}{$\Delta S F>$ Profit } \\
\hline Variables & MOwn1 & MOwnAll \\
\hline NTBD & $-0.2616^{* * *}$ & $-0.3259^{* * *}$ \\
& $(0.0798)$ & $(0.1095)$ \\
MOwn $\cdot$ & $0.3740^{* * *}$ & $0.3428^{* *}$ \\
NTBD & $(0.0979)$ & $(0.1161)$ \\
\hline combined effect & 0.1124 & 0.0169 \\
\hline $\mathrm{N}$ & 30,584 & 30,584 \\
\hline$R^{2}$ & 0.2502 & 0.2509 \\
\hline
\end{tabular}

